\title{
A FIEILD CONFERENCE ON
}

IMPACTS OF COALBED

METHANE DEVELOPMENT IN THE POWDER RIVER

\section{BASIN, WYOMING}

Romeo M. Flores ${ }^{1}$, Gary D. Stricker ${ }^{1}$, Joseph F. Meyer' ${ }^{2}$ Thomas Doll ${ }^{3}$, Pierce H. Norton 4 , Jr., Robert J. Livingston ${ }^{5}$, and M. Craig Jennings ${ }^{6}$

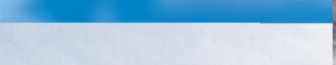

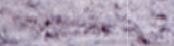

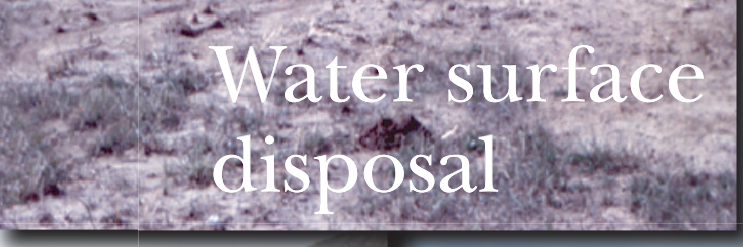

Digital products by Scott A. Kinney ${ }^{1}$, Heather Mitchell ${ }^{1}$, and Steve Dunn ${ }^{1}$

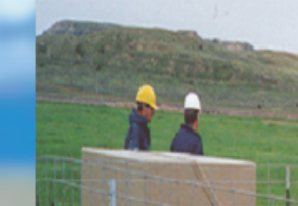

Open-File Report 01-126

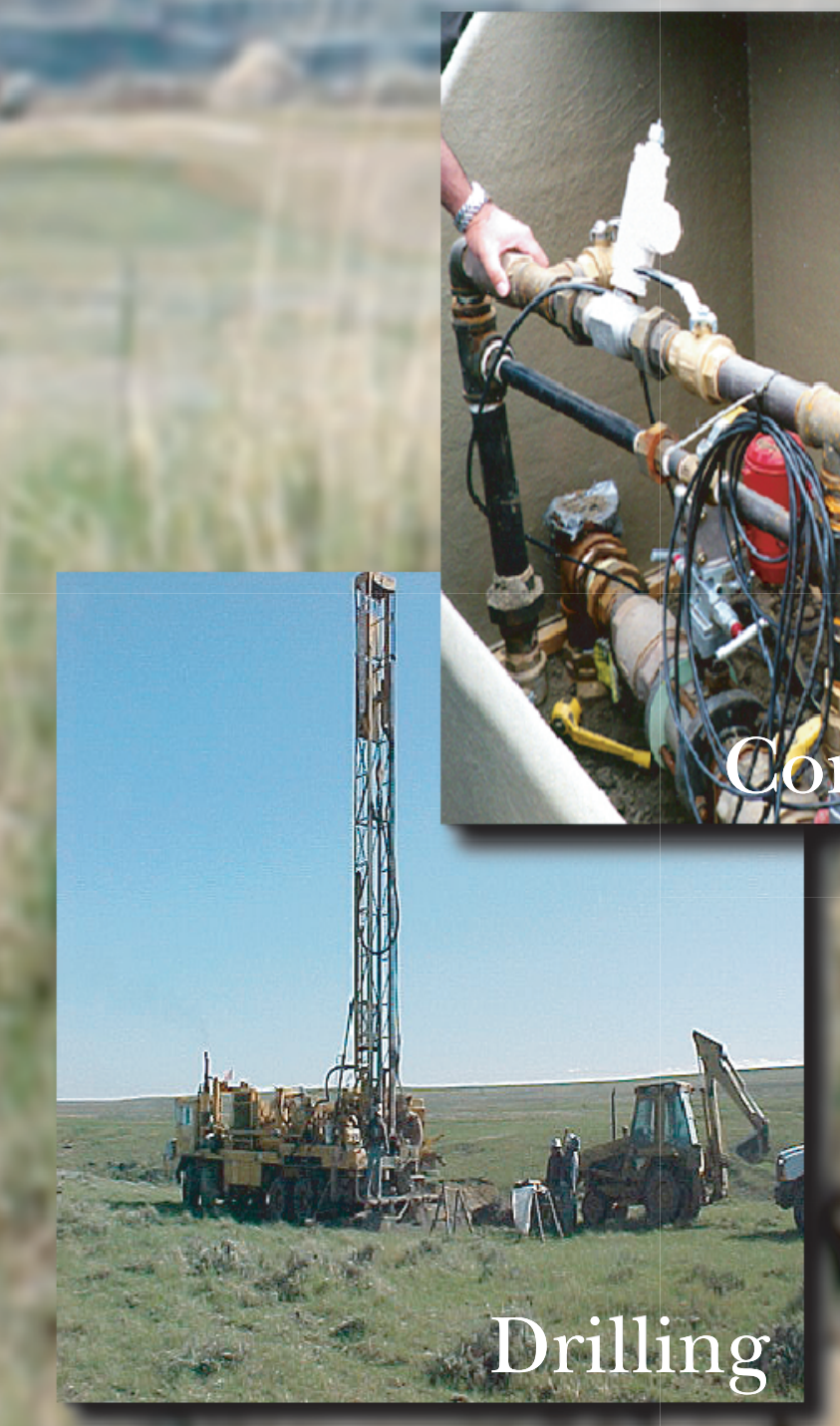

\section{Prospect}

${ }^{1}$ U.S. Geological Survey, Denver, Colorado 80025

${ }^{2}$ U.S. Buream of Land Management, Casper, Wyoming 82601

${ }^{3}$ Barrett Resources Corporation, Gillette, Wyoming 82717

${ }^{4}$ Be:n Paw Energy Inc., Denver Colorado 80202

Ranch Coal Company, Gillette, Wyoming 82717

dy Natural Gas LLC, Gillette, Wyoming 82717

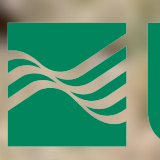




\title{
A FIELD CONFERENCE ON IMPACTS OF COALBED METHANE DEVELOPMENT IN THE POWDER RIVER BASIN, WYOMING
}

\author{
by Romeo M. Flores ${ }^{1}$, Gary D. Stricker ${ }^{1}$, Joseph F. Meyer ${ }^{2}$, Thomas E. Doll', \\ Pierce H. Norton, Jr. ${ }^{4}$ Robert J. Livingston, ${ }^{5}$ and M. Craig Jennings ${ }^{6}$
}

Digital products by Scott Kinney ${ }^{1}$, Heather Mitchell ${ }^{1}$, and Steve Dunn ${ }^{1}$

\section{Open-File Report 01-126}

\section{1}

This report is preliminary and has not been reviewed for conformity with the U.S.

Geological Survey editorial standards or with the North American

Stratigraphic Code. Any use of trade names is for descriptive purposes only and does not imply endorsement by the U.S. Government.

\section{U.S. DEPARTMENT OF THE INTERIOR U.S. GEOLOGICAL SURVEY}

\footnotetext{
${ }^{1}$ U. S. Geological Survey, Denver, Colorado 80025

${ }^{2}$ U.S. Bureau of Land Management, Casper, Wyoming 82601

${ }^{3}$ Barrett Resources Corporation, Gillette, Wyoming 82717

${ }^{4}$ Bear Paw Energy Inc., Denver, Colorado 80202

${ }^{5}$ Jacobs Ranch Coal Company, Gillette, Wyoming 82717

${ }^{6}$ Peabody Natural Gas LLC, Gillette, Wyoming 82717
} 


\section{Introduction}

Coalbed methane (CBM) development from the Paleocene Fort Union Formation coal beds in the Powder River Basin in Wyoming has been rapidly expanding since 1993. During the past ten years the number of CBM producing wells rose to about 4,000 wells as of October, 2000. About 3,500 of these wells were completed since 1998. About 1314 percent of these CBM wells are on Federal lands while the majority are on State and private lands. More than 50 percent of the lands in the Powder River Basin contains mineral rights owned by the Federal government. CBM development on Federal lands creates impacts in the basin resulting from associated drilling, facilities, gas gathering systems (e.g., pipeline networks), access roads, and withdrawal and disposal of coproduced water from CBM wells. The Bureau of Land Management (BLM) assesses the land-use management and impacts of drilling CBM wells on lands where mineral rights are controlled by the Federal government.

In early 1999, BLM (Wyoming Reservoir Management Group) and the U.S Geological Survey (USGS, Central Energy Resources Team) initiated a cooperative project to collect technical data for analysis and evaluation of CBM resources and reservoirs in the Powder River Basin, primarily from coal cores provided by cooperating CBM operators. BLM and USGS need the additional information and analyses of the CBM resources to accomplish their agencies' respective resource evaluation and management missions. The agencies share complementary, but slightly different, goals and information needs. The project also addresses public need for data regarding Powder River Basin CBM resources.

BLM's needs are related to management of CBM resources and primarily include obtaining improved gas content/gas-in-place estimates for reservoir characterization and resource/reserve assessment and evaluation. The USGS has many diverse goals including a basin-wide assessment of CBM resources, developing methodologies for testing gas content of low rank coals, determining the nature and origin of coalbed gases and formation waters using coal petrology, isotopic, and chemical composition, and developing predictive models for assessment of CBM resources in other U.S. and world basins. Although all of the results of this BLM-USGS cooperative CBM project are not yet published, the study has enhanced the understanding of the CBM resources and

reservoirs in the basin. Data provided by the USGS have been utilized internally by BLM in assessing gas-in-place resources, well spacing, reservoir characterization, drainage flow, and lost gas due to mining. Some of the results of this cooperative project 
are presented in this conference and others are shown in a joint BLM-USGS website (www.wy.blm.gov/minerals/og/re's.mgt/resevmgt.html). USGS coal resource estimates and related data from the Powder River Basin study by the Fort Union Coal Assessment Team (1999) have been widely used by the BLM, gas developers, consultants, and Wyoming State Geological Survey.

Field Trip Road Log From Casper to Midwest, Wyoming: 41 MILES (Summarized from road logs by Curry and Crews (1976) and Whitehead (1986); revisions and additions by R.M. Flores). Figure 1 shows the route of the field trip.

Leave Parkway Plaza Parking lot-TURN LEFT and then LEFT onto Interstate 25 onramp. Proceed north on Interstate 25 toward Midwest. Casper Mountain (elevation approximately 8,100 feet) dominates the skyline to the south, which is the northern extent of the Laramie Mountains. These mountains bound the southern limit of the Powder River Basin (Fig. 2).

The North Platte River (mile marker 188.2) is one of the major rivers of the Powder River Basin, yet its drainage basin includes only a small fraction of the present structural basin. The North Platte River originates in the North Park Basin of north central Colorado and flows northward across southern Wyoming, cutting through present topographic features (characteristic of superposed drainage). The river slices through the western end of Casper Mountain at Bessemer Narrows and then flows eastward across the southernmost Powder River Basin to exit over the Hartville Uplift to the southeast.

Casper is at the northeastern limit of the "Wyoming Wind Corridor," a major windchannel crossing southern Wyoming. A broad topographic low in the Continental Divide in the area of the Great Divide (Red Desert) Basin forms a natural channel for the regional flow of westerly winds from the Great Basin. The Casper dune field (north of the city of Casper) was formed in response to west-to-east winds blowing northeastward from the "Wyoming Wind Corridor" through gaps in the Crooks-Green-Ferris-Seminoe Mountain trend. The dune field, with the exception of a few blowouts is now mostly stabilized.

Well-developed, large pebble-and cobble-sized ventifacts (wind-polished stone) are found on deflation surfaces formed on the terrace gravels of the North Platte River. Individual clasts are polished and faceted by wind-driven dust and sand, producing dreikanter (doubly pointed) shapes. Deeply pitted and fluted surfaces on ventifacts are rare here. The 
best-developed ventifacts seem to be cut on dense, hard rock, especially quartzites. Coarse-grained plutonic rocks show little, if any, ventifact development. Ventifacts developed on carbonates and sandstones are rare on the intensely weathered upper surface of the terrace gravel.

North of the Interstate 25 Bypass (mile marker 188.5), we descend a hill and leave the Casper dune field (mile marker 190.3) into the Cody Shale (Upper Cretaceous). For the next 15 miles, we will be slowly moving up-section within the Upper Cretaceous series (Fig. 3). At 2 o'clock (northeast) is a view of Soda Lake. This lake, in a natural depression, is a wastewater disposal pond for the freshwater effluent of the Amoco Refinery. The water supports a diverse migratory bird population and is regularly visited by the local Audubon Chapter.

Cross the underpass for Wardwell Road, Exit 191 (mile marker 191). The cluster of houses coming up on the left (west), marked by a red-capped, blue water tower, is the town of Bar Nunn. Bar Nunn is built around the old Wardwell Airport (old Casper Airport) of World War II vintage. Shortly (at 10 o'clock), you will be able to look down the old (east-west) runway, now with houses on either side and converted into a wide street. This town certainly has the bragging rights for the widest streets in the West. On the right is a grassy roadbed that intersects the interstate. This road is the "old road" (pre-U.S. 25/87) from Casper to the Salt Creek oil and gas field. The right lane (northbound) is concrete and the left lane is asphalt aggregate.

Cross another underpass (mile marker 194.34) while ascending a gentle slope. A borrow pit is on the left (west) at the crest of a low hill. This low, east-west-trending hill of alluvial sand and gravel is mapped as Quaternary terrace or gravel, pediment, and fan deposits. This deposit presumably represents a high-level channel remnant of a west-toeast flowing stream, ancestral to the present-day Casper Creek. Casper Creek originates in the Rattlesnake Mountains, flows across the Wind River Basin and crosses the Casper Arch (west of our location) to join the North Platte River at Casper.

The sandstone bluffs (mile marker 196) on the left (west) are outcrops of the Teapot Sandstone Member of the Mesaverde Formation (Upper Cretaceous). The outcrops are named The Reefs. A "reef' in a geomorphic sense is an old-time term used, especially in the western United States, for a jagged outcrop or hogback that was a barrier to travel. The highway is on the Lewis Shale (Upper Cretaceous; see Fig. 3), which is largely covered by Quaternary sediments. 
To the right (east) of the interstate (mile marker 196), about three-fourths of a mile, is a white-roofed building. This building is part of Nine Mile Lake, an acidic, in-situ, uranium-leaching plant of Rocky Mountain Energy. The uranium (as Uraninite) is in a roll-front type deposit (ore body) at a depth of 500 to 550 feet, in the Teapot Sandstone (see Fig. 3). Sulfuric acid and hydrogen peroxide were injected in a five spot pilot-test area from 1977 to 1978. The Wyoming Department of Environmental Quality requires in situ operators to restore groundwater quality to baseline conditions. From 1978 to 1979, a restoration project, consisting of injection of a mixture of native groundwater and treated, produced water, restored groundwater quality in the leached zone.

Cross the underpass for Ormsby Road - Exit 197 (mile marker 197). At 3 o'clock (about 2 miles east of the interstate) are tank batteries for the Midway oil field. The field, discovered in 1931, is producing oil from a structural trap in the Frontier Formation (see Fig. 3). Cumulative production (as of February 1990) is 373,801 barrels of oil (BO), no gas, and 30,706 barrels of water (BW). The low hills to the right (east), forming the skyline, are developed in the Fox Hills Sandstone (Upper Cretaceous; see Fig. 3). Their rounded, streamlined appearance suggests that they may be yardangs (sharp-crested ridges between round-bottom troughs carved out by wind).

Re-enter the Casper dune field, which occurs, on a narrow, west-to-east trend, extending from the interior of the Wind River Basin across the Casper Arch to the edge of the Powder River Basin. Based on the map patterns of preserved rocks, this area is also an east-west-trending structural low for the Casper Arch. Quaternary sands occupy this structural low of probable Laramide age.

On the right (east) at 3 o'clock, near the skyline, is a glimpse of an active dune blowout. Cross McPherson Draw (mile marker 202.5) and leave the dunal topography. The hill at 1 o'clock is capped by the Lance Formation (Upper Cretaceous; see Fig. 3). Begin a slow drift downsection (see Fig. 3) for approximately 20 miles. On the right (east) is the community of Antelope Hills (mile marker 205-206), built on the Lewis and Fox Hills Formations (Upper Cretaceous; see Fig. 3).

At mile marker 207 is the Twenty-Mile Hill. At 11 o'clock is a microwave relay station. To the right (northeast), there is a brief glimpse of Pine Ridge, developed on Fort Union (Paleocene) rocks. 
At mile marker 210 is the TURNOFF to Highway 259 toward Midwest. The outcrops (mile marker 11.7) on the right (east) include the Upper Cretaceous Lewis Shale (Mowry Shale) overlain by the Fox Hills Sandstone (see Fig. 3). The coal-bearing Teapot Sandstone exposed on the left or west (mile marker 12) underlies these rocks. The "Teapot rock" is exposed immediately north of the Teapot Ranch at mile marker 14.82. This is the type locality of the Teapot Sandstone (Curry, 1976b). Marine shale (mile marker 16) and the coal-bearing Parkman Sandstone (from mile marker 16 to 17.6) underlie the Teapot Sandstone (see Fig. 3). The Parkman Sandstone is underlain by the Cody Shale (see Fig. 3) exposed in the central part of the Teapot Dome (mile marker 21). The road to the U.S. Naval Petroleum Reserve No. 3 toward the Teapot Dome field is at mile marker 21.7. Read "Tempest in the Teapot" for summary of the Teapot Dome field controversy. North of the Teapot Dome field is the Salt Creek Anticline field (mile marker 24-25). The field is flanked on the east (right) and west (left) by the Upper Cretaceous Shannon Sandstone from mile marker 23.5 to Midwest (read summary of Salt Creek field on page 9).

Alternate route: Continue on Interstate 25 from the Highway 259 TURNOFF. The next 24 miles goes gradually downsection through the Mesaverde Formation, Cody Shale and Frontier Formation (Upper Cretaceous; see Fig. 3). The Mesaverde Formation contains bituminous coal beds interbedded with fluvial-deltaic channel sandstones and floodplain siltstones and shales. The Cody Shale includes the Carlile, Niobrara, and Steele Shales in the lower part and the Sussex and Shannon Sandstones in the upper part. The Frontier Formation is exposed along the flanks of the Tisdale Mountain Anticline (Merewether and others, 1976).

Tempest in the Teapot (Summarized from Yergin (1991) by Wheeler (2000); additions by R.M. Flores)

Sinclair Oil Company discovered Teapot Dome (see Fig. 1) in 1922. Curry (1976a) reported that hydrocarbons (oil and gas) occur in the Teapot Sandstone, which was deposited mainly in delta plain and delta front environments. The Teapot Sandstone was first mapped around Salt Creek oilfield by C.H. Wegemann in 1911 and named Little Pine Ridge sandstone. It was renamed by V.H. Barnett in 1913 as Teapot Sandstone from the "Teapot Rock," which is a well known topographic feature carved from this sandstone about half a mile east of the Casper-Salt Creek road. 
Kerogen contained in marine shales above and below the Teapot Sandstone in the deeper part of the Powder River Basin has apparently reached temperatures sufficient to naturally retort the kerogen to oil and gas. Updip migration of these hydrocarbons along fractures led to some accumulation in the Teapot Sandstone, which served as a stratigraphic trap. It is postulated that this general source of hydrocarbons has supplied oil and gas to the Teapot Sandstone reservoirs at Flat Top, Well Draw, Kaye, and other similar undiscovered slope sandstone traps. Although significant volumes of oil and gas have migrated from the deeper part of the basin, hydrocarbons have not yet been found in structural closures.

Though the Teapot Dome is a rather modest field, with cumulative production of just over 30 million barrels of oil (MMBO), it was the focus of a major scandal in the Harding administration. Just prior to World War I the United States and Great Britain both had realized the great advantages of switching from coal to oil to fuel their naval ships. The U.S. made the conversion in 1911. The next year the Taft administration began to establish Naval Petroleum Reserves in areas of potential production. Teapot Dome was one of three field (the others are in California) that were set aside for unexpected emergencies. There were great debates over the establishment of these reserves and whether private interests would be allowed to lease and partially exploit them. These debates were part of a public policy battle at the time between those championing development and others advocating conservation.

Harding won the presidency in 1920 on a platform that celebrated a harmonious relationship between conservation and development. However, his belief in development was revealed when he chose Senator Albert Fall from New Mexico as Secretary of the Interior. Fall was a successful and politically powerful rancher, lawyer and miner. Fall was able to wrestle control of the petroleum reserves away from the Naval Department. In 1922 he leased Teapot Dome to Harry Sinclair with "sweet-heart" terms that assured a guaranteed market with the U.S. Government. He also leased a larger reserve in California, Elk Hill, to Edward Doheny. Both Doheny and Sinclair were well-known American oilmen. The rumors of a shady deal soon began swirling.

Sinclair had built up much of his fortune by investing heavily in the Glenn Pool in Oklahoma. The Oklahoma fields were awash in oil from flush production and were not yet hooked up to pipelines. Sinclair bought all the oil he could get for ten cents a barrel and constructed storage tanks to contain it. When the pipelines were completed, he sold for $\$ 1.20$ a barrel. By WWI Sinclair was the largest oil company in the midcontinent. 
He raised \$50 million and in 1916 assembled one of the ten largest integrated oil companies in the nation.

Soon after the Teapot and Elk Hill leases were signed in 1922, Senator La Follette of Wisconsin began to investigate. He discovered that officers that had opposed the transfer of the petroleum reserves from the Navy to the Department of the Interior were transferred to distant and inaccessible stations. His suspicions were thoroughly aroused when Fall resigned in 1923. Harding suddenly died later that same year and was succeeded by Calvin Coolidge.

The Senate Public Lands Committee took up the matter when it was learned that Fall had begun extensive and expensive renovations on his New Mexico ranch at about the time the leases were signed. Fall also purchased with cash an adjacent ranch.

In subsequent hearings, Sinclair's secretary testified that Sinclair had told him he should give Fall twenty-five or thirty thousand dollars if he ever asked for it. Fall did ask.

The bombshell came on January 24, 1924 when Doheny told the Senate Committee that he had given one hundred thousand dollars in cash to Fall. Doheny insisted it was not a bribe but rather a loan to an old friend with whom he had prospected for gold decades earlier. There was even a hand written note with the signature torn off to substantiate his claim! Doheny claimed that his wife held the signature portion so as not to embarrass Fall with an "inconvenient" claim should Doheny happen to die.

Despite the ongoing scandal, Coolidge managed to get re-elected as President in 1924 based on assurances and testimony that he had no knowledge of the Teapot Dome deal. The scandal dragged on for the rest of the decade. In 1928 it was learned that Sinclair had funneled several hundred thousand more dollars to Fall through the bogus Continental Trading Company, bringing Fall's total gain to over $\$ 400,000$ from his old friends.

In 1931 Fall finally went to jail as the first Cabinet officer ever convicted of a felony while in office. Sinclair was sentenced to six and a half months for contempt and Doheny was judged innocent.

Repercussions of the scandal continued when it was later learned that the Continental Trading Company was a mechanism for a group of prominent oil men to receive kickbacks in the form of government Liberty Bonds for purchases of oil made by their 
own companies. Sinclair had even used some of his as part of his payments to Fall. One of the greatest shocks came when it was revealed that the great and distinguished Colonel Robert Stewart, Chairman of Standard of Indiana (Amoco), had also received kickback bonds. These were the highlights of the Teapot Dome scandal, whose tentacles touched many oilmen and politicians at the time. Unfortunately, it confirmed suspicions about the shady side of the American oil business.

Salt Creek Field - Jackass Spring Oil Seep. (Summarized from road logs by N.H. Whitehead (1986) and History of Salt Creek Area by Art Randall, independent, Casper, Wyoming (unpublished); revisions and additions by R.M. Flores).

Jackass Spring oil seep first created all of the exploration interest in the Shannon and Salt Creek oil fields (see Fig. 1). Jackass Spring is located in the Northeast 1/4, Southwest 1/4, Section 13, Township 40 North, Range 79 West, Natrona County, Wyoming. The Shannon pool is located on the northeast flank of the Salt Creek anticline. Samuel Aughey, Territorial Geologist of Wyoming from 1885-1886, who coined names for all of his claims, named it Jackass.

The first man to attempt to acquire land in the Salt Creek area was Representative Stephen W. Downey, a delegate of Albany County (Wyoming). His first claim was made in 1883 and covered 160 acres of land near the northeast edge of the Salt Creek field and other tracts, one of which contained a prolific oil seep (Jackass Spring). About 1884, A.T. Seymour took claims on the Shannon field to the north.

In May of 1884, Aughey "jumped" Downey's Jackass Spring claim along with John Bothwell. Before the close of 1892, the team of Aughey and Bothwell and a group of New York men became owners of four quarters of the land, of which the Jackass claim was one. Land was not leased in those days but staked as petroleum placer claims. By 1892 the "interest" in Salt Creek had considerably widened. By this time the discovery well, the No. 1 Shannon, was completed in March of 1889. It was drilled to a total depth of about 1,000 feet and was able to produce 5 to 10 barrels of thick paraffin-based oil of about 24 Baume (specific weight of oil). It was located in the Shannon pool north of Jackass Spring oil seep.

One of the most colorful characters to enter the Salt Creek drama was Cy Iba. He learned prospecting in the California gold fields and brought his talents to Wyoming when he began locating and staking oil claims. He also founded the Casper Mountain Mining 
District, and it is in his district that the mining ghost towns of Copperopolis and Eadsville are located. Cy staked some 30 claims in Salt Creek and did the required assessment work. The law required that the assessment work be of the value not less than $\$ 100$ per claim per year. The law also stated that a pit must be dug $6 \times 8$ feet to a depth of 10 feet. This was very easy to do at Salt Creek because of the soft clay (Cody Shale). Two men could do it in a short time of perhaps two hours.

In 1894 a refinery was built in Casper on a small site close to where Center Street crossed the Chicago and Northwestern Railroad tracks. As of the 4th of April 1895, 60 barrels of refined engine oil had been shipped from the refinery.

The drilling of No. 1 Salt Creek (or No. 1 Dutch) in October 1908 opened Salt Creek as one of the most significant fields in the Rocky Mountains. The discovery was made in the First Wall Creek (Frontier Formation) sand in Section 23, Township 40 North Range 79 West; the potential was for 150 barrels of oil per day (BOPD). By Dec 31, 1911, Salt Creek had already produced 66,798 BO. In the Great Depression year 1934, the cumulative production rose to 258,722,178 BO. The upper Cretaceous Frontier Formation has been the main productive interval at Salt Creek, having produced in excess of 432,000,000 barrels of oil (as of 1979). As of 1999, Salt Creek has produced about $675,000,000 \mathrm{BO}$ and 720 billion cubic of gas (data from WOGCC). Nine zones produce at Salt Creek and from the oldest to the youngest they are: Pennsylvanian Tensleep Sandstone, upper Jurassic Sundance and Morrison Formations, lower Cretaceous Lakota Sandstone and Shale, Lower Cretaceous Third Wall Creek, Second Wall Creek, and First Wall Creek Sandstones, and Upper Cretaceous shales.

In 1923, the North and South Railroad was built from Illco Junction on the Chicago and Northwestern Line just to the northwest of Casper, Wyoming to Salt Creek. This railroad line was short-lived, as larger pipe lines were used to move the oil rather than using the railroad tank cars. In 1925 Salt Creek became one of the first oil fields in the country to be powered totally by electricity.

The boom days of Salt Creek in the twenties and thirties caused many business buildings to be built in downtown Casper and most of them are still standing today.

As of October 1989, the Salt Creek field has 1,196 wells and the cumulative production is 633,342,574 BO, 711,666,946 thousands of cubic feet of gas (MCFG) (as of December, 1988 ) and $3,865,237,488 \mathrm{BW}$. Truly a giant! 
Field Trip Log from Midwest-Edgerton to Wright-Reno Junction, Wyoming: 51 miles (by R.M. Flores)

Follow Highway 387 from Midwest through Edgerton, which is on the Cody Shale (mile marker and associated Shannon Sandstone (mile marker 100.5; see Fig. 3). The origin of the sandstone is controversial and has been interpreted to be shelf ridge, lowstand facies tract (erosional-based shoreface), and paleovalley (tidal bars, estuarine) sand bodies (Bergman and Snedden, 1999).

The Shannon Sandstone is an important oil and gas reservoirs in the Heldt Draw Field in the west-central part of the Powder River Basin (Todd Davis, 1976; Spearing, 1976). As many as three sandstones (silty and fine-grained) serve as stratigraphic traps for hydrocarbons.

The coal-bearing Parkman Sandstone of the Mesaverde Formation (see Fig. 3) is exposed immediately north of Edgerton (mile marker 103). In the next 12 miles, we begin a gradual ascent from the Upper Cretaceous section (see Fig. 3) of the Cody Shale through the Mesaverde Formation (mile marker 102.5-103.8), Lewis Shale (mile marker 105107), Fox Hills Sandstone (mile marker 109), and Lance Formation (mile marker 110112). The Lance Formation is coal bearing and is conformably overlain by the Paleocene Fort Union and overlying Eocene Wasatch Formations. Coals of the Fort Union Formation are the principal coalbed methane producing beds in the Powder River Basin. A few coal beds in the Wasatch Formation also produce coalbed methane.

After leaving the Lance Formation, we cross the Pine Ridge (mile marker 113.2), which marks sandstone outcrops of the Fort Union Formation. Pine trees commonly grow on these sandstones, which serve as aquifers. Descend into the drainage basin of the Powder River that drains the south-central part of the basin and flows to the northeast joining the Yellowstone River in southeast Montana, which in turn, drains into the Missouri River.

In the next 36 miles to Wright-Reno Junction, the basin is covered by the Wasatch Formation, which is overlain by the Oligocene White River Formation (see Fig. 3), exposed in the Pumpkin Buttes to the north. The White River Formation consists of volcaniclastic sandstones, siltstones, conglomerates, and tuffaceous rocks. Uranium occurrences in the Pumpkin Buttes were first reported by Love (1952). In 1954 two major areas in the southern part of the Powder River Basin were identified to contain potential uranium resources: 1) Pumpkin Buttes-Turnercrest area in parts of Johnson, 
Campbell, and Converse Counties, and 2) Monument Hill-Box Creek area in Converse County (Curry and Crews 1976). Uranium ores in the form of uraninite occur in permeable arkosic fluvial channel sandstones in the uppermost part of the Fort Union and Wasatch Formations (see Fig. 3). The ores were formed as roll front deposits resulting from a geochemical front that precipitated the minerals along a facies change of coarse to fine clastic sediments (Buturla and Schwenk (1976).

Grasslands that mainly support cattle ranching cover the Powder River Basin. The creeks that run through these grasslands are intermittently dry. In this part of the basin land use is mainly agricultural and range land. The majority of the surface here is privately owned (e.g., Iberlin, Moore, and Taylor Ranches). About 55 percent of the subsurface minerals, such as coal, in the Powder River Basin are Federally owned and managed by the U.S. Bureau of Land Management (Fig. 4). The rest of the subsurface mineral ownership is State or private.

The southernmost extent of Powder River Basin CBM development in Campbell County occurs immediately south and north of Highway 387 and east of Highway 50 (mile marker 123-147; Fig. 5). The Fort Union coal beds (Fig. 6) that are producing coalbed methane in this part of the Powder River Basin are shown in a composite stratigraphic column and a series of north-south and east-west cross sections (Figs. 7-11). Figures 8, 9, 10 and 11 show the thick coal beds of the Wyodak-Anderson coal zone (sometimes informally named as Big George and Sussex coal zones), which produce coalbed methane. These coal beds mainly occur from 1,000 to 2,000 ft below the surface (Fig. 12). The CBM well spacing in the Powder River Basin varies from 40 (16 wells per section) to 80 (8 wells per section) acres. The Wyoming Oil and Gas Conservation Commission recently issued an order of 80 -acre spacing basinwide unless a gas operator requests and justifies an exception of this well spacing.

Five CBM fields are being developed along Highway 387 (see Fig. 5). These fields include from southwest to northeast (towards Wright), the Pine Tree (mile marker 123129; Devon Energy Corporation), Allnight Creek (mile marker 137.6-143.4; Barrett Resources Corporation), K Bar (Yates Petroleum Company), House Creek (mile marker 146-146.7; Devon Energy Corporation), and North Wright (Barrett Resources Corporation). The Pine Tree and House Creek fields are both conventional oil and gas, and CBM fields. These CBM fields were discovered in 1997 and are the youngest to be developed in the Powder River Basin. The oldest CBM fields (e.g., Marquiss) occur between Wright and Gillette and Highways 59 and 50 (Fig. 13). In that area, 
development began in the early 1990's in the old Lighthouse and Marquiss coalbed methane project areas. Since then development rapidly expanded from that project area in all directions, but especially toward the north, west, and south. These areas of early development by Barrett Resources Corporation and Lance Oil and Gas Company (Western Gas) were identified by the U.S. Bureau of Land Management (BLM) as the Gillette South Assessment Area (Bureau of Land Management, 1999). That area and an area of additional development in the Gillette North Assessment Area located in central Campbell and northern Converse Counties, within the eastern Powder River Basin were named by BLM as the Wyodak CBM project Environmental Impact Statement (EIS) area (see Figs. 1 and 2). During the last several years, development has extended westward outside the Wyodak CBM (EIS) project area.

The amount of methane produced from all wells and from wells on federal leases in billions of cubic feet of gas (BCFG)/month as well as the average amount of gas per well per day in thousand cubic feet of gas (MCFG) from January, 1990 to October, 2000 is shown in Figure 14. The number of wells in production over the same time period is shown in Figure 15. As of October 30, 2000, the total CBM production was about 15 billion cubic feet of gas or bcf/month and the rate was about $120 \mathrm{MCF} /$ day/well. CBM production from Federal leases was about $2.5 \mathrm{bcfg} / \mathrm{month}$ at a rate of $25 \mathrm{MCF} / \mathrm{day} /$ well (see Fig. 14). A rapid increase of CBM production occurred last year (2000). This increase may be explained by the astronomical rise of producing wells of about 3,000 wells, in one year (see Fig. 15). The range in depth of producing CBM wells is from less than 200 to greater than 2,200 ft (see Fig. 16). Fifty percent of the CBM producing wells have depths ranging from 400 to $800 \mathrm{ft}$. Water co-produced with coalbed methane in the Powder River Basin, Wyoming is shown in Figure 17. As of October 30, 2000, the total co-produced water was about 37 million barrels/month at a rate of about 370 barrels per day per well. Co-produced water from Federal leases is about 4 million barrels/month at a rate of about 400 barrels per day per well. During the ten-year period from January, 1990 to January, 2000) the rate of production, water ranged from 30 to 480 barrels per day per well. However, one well in the west-central part of the basin produced as much as 4,800 barrels of water per day.

\section{Impacts and Issues of CBM Development (by R.M. Flores)}

Production of coalbed methane usually involves withdrawing water from the coal bed to lower the reservoir pressure and allow the methane to desorb from the coal. A major 
impact related to dewatering the coal beds is groundwater drawdown resulting from lowering of the water table. A computer simulation of groundwater drawdown modeled by Bureau of Land Management (1999) is shown on Figure 18. This simulated drawdown attributed to CBM development for the Wyodak-Anderson coal zone during the 15-year period to 2015, shows maximum drawdown of as much as $550 \mathrm{ft}$ in the Gillette South assessment area and about 300 to $375 \mathrm{ft}$ in the southern and northern parts (north of Gillette) of the EIS area, respectively.

Another major concern of CBM development is the effect of surface disposal of coproduced water and the effect of this additional water on watersheds within the EIS project area. Figure 19 is a map of the major watershed areas and related drainages of the Belle Fourche, Cheyenne, Powder, and Tongue River basins as well as Caballo Creek. Co-produced water from CBM development is presently discharged either directly into exiting surface waters or to drainages. The Wyoming Pollutant Discharge Elimination System (WPDES) permits surface discharge because the water is generally potable (freshwater), mainly low total dissolved solids (TDS), and of good quality. Total dissolved solid, $\mathrm{pH}$, chloride, and sulfate concentrations in the produced water are near or lower than the levels recommended for drinking water standards (Rice and others, 2000; Table 1). It is expected that surface disposal of co-produced water may result in erosion or drowning of drainage draws and associated vegetation within the project (BLM/EIS) area (see Figs. 1 and 2). Several companies have been experimenting with reinjecting the produced water into sandstones and coal beds in the Wasatch and Fort Union Formations. Pennaco Energy is presently reinjecting water into an aquifer used by the city of Gillette (Tollefson, 2000).

Groundwater withdrawal from aquifers is a particularly sensitive issue to landowners who "beneficially use" groundwater for their livestock and for irrigation. Generally, gas operators have cooperated with landowners by diverting co-produced water from CBM wells into stock tanks or other holding areas for their livestock.

Another important issue related to co-produced water is the effect of the water composition on soils. The sodium absorption ratio or SAR is a calculated parameter comparing the amount of sodium in the water versus the amounts of calcium and magnesium and is frequently used in agricultural applications to determine the compatibility of irrigation water and soils. The SAR is a measure of the tendency of the sodium to replace other cations in clays in the soil, potentially reducing soil permeability, with higher SAR values favoring replacement. Higher water SAR values may limit 
surface disposal of co-produced CBM waters in some areas depending on where the water is being discharged and the soil characteristics in that area. Initial results of co-produced water analyses indicate the SAR values increase from southeast to northwest in the basin (Fig. 20; Rice and others, 2000).

CBM development impacts the mining of the same coal beds along the eastern margin of the Powder River Basin. There are 18 surface coal mines (Fig. 21) along the eastern part of the Campbell County and the northernmost part of Converse County (Fort Union Coal Assessment Team, 1999, Flores and others, 1999). Last year, these coal mines produced about 300 million short tons from the Wyodak-Anderson coal zone, which is being explored and developed for CBM by about 80 gas operators basinwide. The produced coal from these mines made up about 30 percent of the total U.S. coal production in 2000 and was shipped to more than 140 electric-power generating plants in the western, midwestern, southern, and southeastern U.S. Minor amounts of this coal is shipped to foreign countries (Canada, France, and Spain). The major impact of CBM development on coal mining is groundwater withdrawal from the coal. Although this does not affect the amount of coal that is produced, it reduces the available water for mining operations. In addition, the conflicts between coal mines and CBM operators arise in regard to lost gas due to mining. That is, because water is withdrawn during surface mining, reservoir pressures can be reduced resulting in the liberation of stored gas in the coal, which may escape along mine highwalls. The joint USGS-BLM CBM cooperative project is currently involved in the resolution of this conflict by estimating the gas content of the coal beds within the area of coal mine and CBM leases. Results of this study are published and listed on the joint USGS-BLM website (www.wy.blm.gov/minerals/og/res.mgt.html) maintained by the Wyoming BLM office in Cheyenne.

Field Trip Stops (by R.M. Flores)

The impacts and other issues related to CBM development and coal mining in the Powder River Basin, Wyoming will be observed and addressed at 4 stops in this field conference. The stops will demonstrate the effects of drilling for CBM, CBM production, surface drainage of co-produced water, water quality, gas collection, and coal mining operations. Activities at all 4 stops are co-sponsored by gas and coal developers that collaborate with the USGS-BLM CBM cooperative project. 


\section{Stop 1: Jacobs Ranch Coal Mine (Leaders: Rob Livingston, Jacobs Ranch Coal Co., Kennecott Energy, Gillette Wyoming and Romey Flores, USGS)}

At Reno Junction TURN RIGHT onto Highway 59 (mile marker 75.06; see Fig. 1). About 3 miles south on Highway 59 TURN LEFT (mile marker 72.39) onto Highway 450 (mile marker 66.2) and proceed about 12 miles to Jacob Ranch Coal Company (a subsidiary of Kennecott Energy) headquarters (mile marker 54.4). Thunder Basin Coal Mine (Arch Mineral) is located south of Highway 450. The Jacobs Ranch Coal Mine (Fig. 22) opened in 1978 and produced about 300 million short tons of coal during the first 20 years of operation. The mine produces from the Wyodak-Anderson coal zone, which is locally named Wyodak by the operator. Here the coal zone consists of three coal beds; the lower, middle, and upper Wyodak seams; separated by shale beds. The lower Wyodak seam is $5 \mathrm{ft}$ thick and is not economic. The middle Wyodak seam varies from $35 \mathrm{ft}$ thick in strip pit 2 to $50 \mathrm{ft}$ thick in strip pit 1 (Fig. 23). The upper Wyodak coal seam varies from 7 to $10 \mathrm{ft}$ thick and is also being mined. The strip ratio (thicknesses of overburden rocks and coal and) is from 2.5:1 to 3:1 with the overburden or rocks above the coal zone varying from 150 to $200 \mathrm{ft}$ thick. The overburden consists of mainly sandstone and mudstone (Fig. 23).

The coal is subbituminous in rank with an average calorific value of about $8,700 \mathrm{Btu} / \mathrm{lb}$ and an average of 0.45 percent total sulfur and 5.4 percent ash yield. Jacobs Ranch Coal Mine is permitted to produce 35 million short tons of coal annually, however, last year the total annual production of was about 30 million short tons. Jacobs Ranch is served by two railroads and a top-off precision loading system, which permits two trains to load simultaneously. The coal is shipped to electric power generating plants in the southern and southeastern United States (Texas, Alabama, Georgia, and Tennessee). The projected life of the coal mine is to the year 2006. The remaining coal reserve is estimated at 240 million short tons and the coal has an average thickness of $55 \mathrm{ft}$. Presently the coal mine has applied (Lease By Application) for a lease tract that contains as much as 530 million tons of coal reserve, which should extend the life of the mine beyond 2006.

The Jacob Ranch Coal Mine was involved in the "lost gas" issue and the company cored 2 wells for the USGS-BLM CBM project to determine the gas content of the WyodakAnderson coal zone in their mine property west of strip pit 1 (see Fig. 22). RIM Operating, Inc. in their lease area west of the Jacobs Ranch Coal Mine property, for our study, cored an additional 2 wells. The average gas content sampled about $500 \mathrm{ft}$ from 
the mine highwall is about 1-2 standard cubic feet per ton of coal (scf/t) compared to 12 scf/t about 3 miles to the west of the mine highwall.

\section{Stop 2: Dry Fork CBM Field (Leaders: Tom Doll, Barrett Resources Corporation, Gillette, Wyoming; Joe Meyer, BLM, Casper, Wyoming, and Romey Flores, USGS, Denver, Colorado)}

Return to Highway 450 from the parking lot of Jacobs Ranch Coal Company (see Fig. 1). TURN RIGHT (west) on Highway 450 and proceed about 8.6 miles. TURN RIGHT (north) about 0.7 mile after the Highlight Road on a "scoria" road (mile marker 63) and proceed about 1 mile. This stop is at the Dry Fork CBM field (Fig. 24), which has been operated by Barrett Resources Corporation for about a year. The Dry Fork field is one of three fields (Dry Fork, Greater Black Thunder, and Little Black Thunder) operated by Barrett in this area. The field consists of 80 producing wells that are more than $700 \mathrm{ft}$ deep (Fig. 24). These CBM wells produce gas from the Wyodak-Anderson coal zone, which is locally identified as Wyodak coal by the gas operator. Here the WyodakAnderson coal zone is more than $70 \mathrm{ft}$ thick and consists of as many as 6 coal seams interbedded with thin carbonaceous shale and mudstone partings (Figs. 25 and 26). Toward the basin center the coal zone is locally split, and contains shale and mudstone beds that are thicker than the coal seam above and below. Fluvial channel sandstones and associated floodplain-crevasse splay mudstones, siltstones, and sandstones overlie the coal zone. The CBM wells within the 4-township area currently produce a total of 40 million cubic feet per day (MMCF/day). The gas from the CBM wells is piped to pod stations, where it is metered. Each pod station serves as many as 8 wells. The gas is comingled and is piped to a rotary compressor which compresses the gas to about 80 pounds per square inch (psi). The gas is then piped to a main line compressor where the gas is compressed to about 1500 psi. Western Gas (Lance Oil and Gas Company) operates the pipeline infrastructure in this area. The CBM wells in this area produce an average of 400 barrels of water per day per well. The co-produced water is discharged into the North Fork of the Dry Fork of Little Thunder Creek, which eventually feeds into the Cheyenne River.

Surface water discharge from CBM wells along the Caballo and Upper Belle Fourche Creeks (see Fig. 19) have been monitored for the last few years by the Casper District Office of the BLM (Meyer, 2000). A major issue concerning the discharge of water on the surface by CBM wells concerns the volume of water produced and the effect on flow rates in nearby streams. BLM has investigated this problem and monitored water gages 
from 1993 to 1999 along the Caballo Creek and Belle Fourche drainages (see Fig. 19). Streamflow volumes at the gaging stations show little or no increase that can be related to the introduction of CBM co-produced water (Meyer, 2000). Streamflow events in the Caballo and Upper Belle Fourche drainage basins are mainly related to precipitation (e.g., rain and snow), with streamflow returning to near zero flow during periods of little or no precipitation. Creeks in these drainage basins are ephemeral with flow occurring in response to storm events and snowmelt. On average, flow on Caballo Creek during periods of significant precipitation represents less than 2 percent of the total volume of water produced from CBM wells (Meyer, 2000). The Upper Belle Fourche Creek exhibits flow very similar to that of Caballo Creek; that is the flow averages less than 3 percent from co-produced water. Thus, none or very little of the water discharge from CBM wells makes it to the stream gage locations on the Caballo and Upper Belle Fourche Creeks. During periods of little or no precipitation evapotranspiration and infiltration losses may be greater than 90 percent (Meyer, 2000). Similar trends have been observed in the Little Powder River drainage basin.

\section{Stop 3: Peabody Natural Gas Drill Site (Leaders: Gary Stricker and Romey Flores, USGS, Denver Colorado; Craig Jennings. Peabody Natural Gas LLC, Gillette, Wyoming)}

Return to Highway 450 and proceed west to Highway 59 (see Fig. 1). TURN RIGHT (north) toward Gillette, Wyoming. CBM development is extensive for a distance of about 35 miles, from north of Wright to south of the city of Gillette. Most of the development is west of Highway 59, where there are numerous CBM fields operated by several gas operators (e.g., Barrett Resources Corporation, Western Gas, Huber JM Corporation, Peabody Natural Gas LLC, Yates Petroleum Company, Devon Energy Corporation, Pennaco Energy, Inc., Ocean Energy Resources, Inc.). The coalbed methane is produced from the Wyodak-Anderson coal zone, which averages about $50 \mathrm{ft}$ thick and is as much as $100 \mathrm{ft}$ thick. The net total thickness of coal beds in the WyodakAnderson coal zone is shown in Figure 27. The vertical and lateral variations of coal beds in the Wyodak-Anderson coal zone between Wright and Gillette are illustrated by a east-west cross section (see Fig. 11)

Some of the CBM fields that were developed in the 1980's and early 1990's, are gradually being depleted of gas such that some operators are using vacuum pumps to prolong the life of these wells. The average life of a CBM well is about 7 to 8 years. In this area, several gas operators have plans to explore and develop a zone of coal beds 
(e.g. Cache, Wall, Pawnee, and Kennedy) below the Wyodak-Anderson coal zone (Fig. 28). This zone of coal beds below the Wyodak-Anderson has net coal thickness of over $200 \mathrm{ft}$ in the east-central part of the Powder River Basin (see Fig. 28), where the uppermost coal beds in this zone occur from 1,000 to 2,000 ft below the surface. This is shown by the thickness of overburden rocks to the top of the uppermost coal bed in this zone (Fig. 29).

TURN left (mile marker 96.95) on Hoe Creek road and proceed west for about 4 miles. This stop is to visit a site of Peabody Natural Gas drill site to observe drilling operations prior to CBM development. Peabody is drilling for coalbed methane from coal bed below the Wyodak-Anderson coal zone. The CBM wells are drilled by truck mounted rigs as shown in Figure 30. The truck-mounted rig can drill to about 3,000 ft below the surface. The drill rig is operated by at least 2 to 3 people (a driller and 1 or 2 assistants). Because the CBM wells are shallow in the Powder River Basin, the drilling equipment is smaller than what is required for a conventional oil and gas well. There are about 108 truck-mounted rigs operating in the Powder River Basin with about 70 of these operating at any given time. With this many drilling rigs, the basin currently has the highest level of drilling activity of any onshore basin in the United States. What makes the CBM wells economical is that they are shallow $(<1,000 \mathrm{ft}$ from the surface) allowing inexpensive (about $\$ 25,000$ for wells less than 1,000 ft deep) drilling and well completion in only a few days (McGarry, 2000). Drilling and completion costs of deeper CBM wells average about $\$ 68,000$ (Shirley, 2000).

\section{Stop 4: The Gap Gas Gathering Complex (Leader: Pierce Norton, Bear Paw Energy, Denver, Colorado)}

Return to Highway 59 and TURN LEFT (north) towards Gillette, Wyoming (see Fig. 1). Proceed to the Gap gas-gathering complex of Bear Paw Energy about 10 miles south of Gillette (Fig. 31). About 6.3 miles TURN LEFT on McCreery road and proceed about 1-1.5 miles to South Jim Wolff (first stop; see Fig. 31) and Antelope Valley compressor stations (second stop; see Fig. 31). These compressor stations started in November, 1999. The South Jim Wolff station gathers gas from Pennaco Energy (Marathon Oil Company), Coleman Oil and Gas Inc., and Torch Oil and Gas Company) wells to pod stations, which in turn is compressed to 75-80 psi by Screw compressors. This gas is then moved to the Antelope Valley station where reciprocating compressors compress it to about 1,200 psi. 
The Gap gas-gathering complex has been in operation for about 2 years and started flowing gas in May 1999. Bear Paw Energy gathers gas in the Gap from 449 CBM wells. The gas gathering system consists of 10 pod stations with each station serving 20 to $60 \mathrm{CBM}$ wells. The gas from each well is metered in the pod station and is commingled prior to being piped to screw and reciprocating compressors. The gas is put into pipelines interconnecting to the Fort Union and Thunder Creek 24-inch pipelines (Fig. 32). The gas is either moved north to North Dakota through the Williston Basin Interstate pipeline or it is moved to the south (Nebraska, Kansas, the Front Range of Colorado and California) through the Glenrock pipeline.

The Gap gas-gathering complex moves a total of 46 MMCFG/day through 535 miles of low pressure lines (from wells to pod stations), 35 miles of intermediate gathering system (from pod stations to the reciprocating compressors), and 18.5 miles of high pressure lines (from the reciprocating compressors to the main pipelines). It cost about $\$ 45,000,000$ to build the Gap gas-gathering complex. Since 1999 the pipeline infrastructure (see Fig. 32) in the Powder River Basin has been expanded to 550 miles of 16, 20 and 24 inch pipelines at a cost of $\$ 443$ million (Bear Paw Energy, personal communication, 2000). The new pipeline infrastructure (e.g., Thunder Creek, Fort Union, and Medicine Bow) is 7 to 84 percent utilized.

The major impact demonstrated by this last stop in the Gap gas-gathering complex is its effect on the "urban interface environment." CBM development has encroached south of the city limit of Gillette. In addition, CBM development has impinged on residential subdivisions west and north of the city limits of Gillette. Drilling for CBM near or in residential areas is a conflict between landowners and gas operators because of possible invasion of privacy and devaluation of residential properties. In order to avoid devaluation of property, CBM wellheads and metering equipment are housed in tan fiberglass well covers to blend in with the environment. Also, safe collection of the gas is an issue especially because the coal reservoir extends below residential areas. This issue is particularly important because of potential hazardous migration of CBM inside homes as exemplified in the Rawhide Village subdivision (10 miles north of Gillette) (Jones and Taucher, 1989). Based on field and laboratory studies of methane and hydrogen sulfide gas concentrations underlying the Rawhide Village subdivision, Glass and others (1987) and Jones and others (1987) reported that the entire subdivision was underlain by potentially explosive concentrations of methane (defined between 5 and 15 percent methane). The Rawhide Village subdivision was subsequently abandoned. 
Dewatering of coal lowers the water table, which in turn, may allow gas to seep. However, gas collection may help prevent gas seepages.

\section{Return to Casper}

Two optional routes can be taken on the return to Casper. One route (longer) is to return to Highway 59 and TURN LEFT (south) toward Wright/Reno Junction and turn west on Highway 387 toward Midwest/Edgerton. The other route is to TURN RIGHT or north toward the City of Gillette and TURN left or west on Skyline Road through the southern city limits. TURN LEFT or south on Highway 50, which intersects with Highway 387 at Pine Tree, about 19.5 miles west of Wright/Reno Junction. The second route (shorter) may be delayed by construction along the highway. Taking Highway 50 presents an opportunity to observe activities along the western limit of CBM development. From Gillette to the Pine Tree intersection is about 50 miles.

\section{References Cited}

Bergman K., and Snedden, J., eds., 1999, Isolated shallow marine bodies: sequence stratigraphic analysis and sedimentologic interpretations: Society of Economic Paleontologists and Mineralogists, Special Publication 64, 300 p.

Bureau of Land Management, 1999, Wyodak coal bed methane project draft environmental impact statement: U.S. Department of Interior, Bureau of Land Management, Buffalo Field Office, p. 4-22-4-61.

Buturla, F.J., and Schwenk, M.E., 1976, The Bear Creek uranium project, in Laudon, R.B., Curry, W.H., III, and Runge, J.S., eds., Geology and Energy Resources of the Powder River. 28 $8^{\text {th }}$ Annual Field Conference Guidebook, Wyoming Geological Association, p. 231-234.

Curry, W.H., III, 1976a, Late Cretaceous Teapot delta of southern Powder River Basin, Wyoming, in Laudon, R.B., Curry, W.H., III, and Runge, J.S., eds., Geology and Energy Resources of the Powder River. 28th Annual Field Conference Guidebook, Wyoming Geological Association, p. 21-28.

Curry, W.H., III, 1976b, Type section of the Teapot sandstone, in Laudon, R.B., Curry, W.H., III, and Runge, J.S., eds., Geology and Energy Resources of the Powder River. 28th Annual Field Conference Guidebook, Wyoming Geological Association, p. 2932.

Curry, W.H., III and Crews, G.C., 1976, Field trip log upper Cretaceous sandstones, Casper-Salt Creek-Tisdale Mountain, in Laudon, R.B., Curry, W.H., III, and Runge, 
J.S., eds., Geology and Energy Resources of the Powder River. 28th Annual Field Conference Guidebook, Wyoming Geological Association, p. 312-321.

Ellis, M.E., Gunther G.C., Ochs, A.M., Roberts, S.B., Wilde, E.M., Schuenemeyer, Power, H.C., Stricker, and Blake, D. 1999, Coal resources, Powder River Basin, in 1999 Resource assessment of selected Tertiary coal beds and zones in the northern Rocky Mountains and Great Plains region: U.S. Geological Survey Professional Paper 1625-A, Chapter PF, p. PF1 to PF37.

Flores, R.M., Ochs, A.M., Bader, L.R., Johnson, L.C., and Vogler, D., 1999, Framework geology of Fort Union coal in the Powder River Basin, in 1999 Resource assessment of selected Tertiary coal beds and zones in the northern Rocky Mountains and Great Plains region: U.S. Geological Survey Professional Paper 1625-A, Chapter PF, p. PF1-35.

Fort Union Coal Assessment Team, 1999, 1999 Resource assessment of selected Tertiary coal beds and zones in the northern Rocky Mountains and Great Plains region: U.S. Geological Survey Professional Paper 1625-A, Discs 1 and 2, version 1.1.

Glass, G.B., Jones, R.W., and De Bruin, R.H., 1987, Investigation of the potential for near-surface explosive concentrations of methane to occur in the Rawhide Village Subdivision, Campbell County, Wyoming: Geological Survey of Wyoming report for the Wyoming Department of Environmental quality (unpublished), 7 p., 3 pls.

Jones, R.W., and Taucher, P.J., 1989, Coal geology, geophysical logs, and lithologic descriptions from a drilling program at the Rawhide Village subdivision, Campbell County, Wyoming: Geological Survey of Wyoming Open-File Report 89-2, 59 p.

Jones, R.W., De Bruin, R.H., and Glass, G.B., 1987, Investigations of venting methane and hydrogen sulfide gas at Rawhide Village, Campbell County, Wyoming, in Rawhide II Project Report, Appendix I. Geology: Geological Survey of Wyoming, Laramie, Wyoming (unpublished), 23 p. 12 pls.

Laudon, R.B., Curry, W.H., III, and Runge, J.S., eds., 1976, Geology and Energy Resources of the Powder River. 28th Annual Field Conference Guidebook, Wyoming Geological Association, $350 \mathrm{p}$.

Love, J, D., 1952, Preliminary report on uranium deposits in the Pumpkins Buttes area, Powder River Basin, Wyoming; U.S. Geological Survey Circular 176, 37 p.

McGarry, D.E., 2000, Challenges in assessment, management and development of coalbed methane resources in the Powder River Basin, Wyoming: The Proceeding of the 25th International Technical Conference on Coal Utilization and Fuel Systems, p. 709-720.

Meyer, J. 2000, Coal bed methane produced water-infiltration/evapotranspiration, Belle Fourche River basin, 1993-1999: Bureau of Land Management Report. 12 p. 
Merewether. E.A., Cobban, W.A., and Spencer, C.W., 1976, The upper Cretaceous Frontier Formation in the Kaycee-Tisdale Mountain area, Johnson County, Wyoming, in Laudon, R.B., Curry, W.H., III, and Runge, J.S., eds., Geology and Energy Resources of the Powder River. $28^{\text {th }}$ Annual Field Conference Guidebook, Wyoming Geological Association, p. 33-44.

Rice, C.A., Ellis, M.E., and Bullock, J.H., Jr., 2000, Preliminary data on Powder River Basin coalbed methane waters in Wyoming: U.S. Geological Survey Open-File Report, $25 \mathrm{p}$.

Shirley, K. 2000, Wyoming enjoys coal gas play: American Association of Petroleum Geologists Explorer, April issue, p. 16-24.

Spearing. D.R., 1976, Upper Cretaceous Shannon sandstone: an offshore, shallow-marine sand body, in Laudon, R.B., Curry, W.H., III, and Runge, J.S., eds., Geology and Energy Resources of the Powder River. 28th Annual Field Conference Guidebook, Wyoming Geological Association, p. 65-72.

Todd Davis, M.J., 1976, An environmental interpretation of the upper Cretaceous Shannon sandstone, Heldt Draw Field, Wyoming, in Laudon, R.B., Curry, W.H., III, and Runge, J.S., eds., Geology and Energy Resources of the Powder River. 28th Annual Field Conference Guidebook, Wyoming Geological Association, p. 125-138.

Tollefson, J, 2000, Petition seeks to stall permits: water, property tights cause for concern: Casper Star Tribune, B5-B6.

Wheeler, D., 2000, The tempest in the teapot, in Flores, R.M., Powder River Basin Field Guidebook, Society of Economic Paleontologists and Mineralogists, Rocky Mountain Section, 3 p.

Whitehead, N.H., 1986, Field trip road log: 1986 Symposium on Rocky Mountains Oil and Gas Fields, Wyoming Geological Association, 6 p.

Yergin, D., 1991, The Price: The Epic Quest for Oil Money and Power: Chapter 11, Touchstone Publisher, New York, N.Y., p. 211-216. 


\section{List of Figures}

Figure 1. Map showing the routes and stops for the field conference in the Powder River Basin, Wyoming, and BLM Environmental Impact Statement (BLM/EIS) project area boundary.

Figure 2. Tertiary geological map of the Powder River Basin, Wyoming and Montana showing the axis of the basin and BLM/EIS project area boundary.

Figure 3. Generalized stratigraphic column of the Upper Cretaceous and Tertiary rock units in the Powder River Basin, Wyoming. Modified from Laudon and others (1976).

Figure 4. Map showing subsurface mineral ownership in the Powder River Basin, Wyoming and Montana.

Figure 5. Map showing the locations of permitted CBM wells in the Powder River Basin, Wyoming and Montana and CBM fields in the southern part of Campbell County, Wyoming.

Figures 6. Composite stratigraphic column of the Fort Union Formation and associated rock units in the Powder River Basin. Adapted from Flores and others (1999).

Figure 7. Map showing locations of regional stratigraphic cross sections of the Paleocene Fort Union Formation and associated CBM producing coal beds and zones in the Powder River Basin, Wyoming and Montana. Adapted from Flores and others (1999).

Figure 8. North-south cross section (B-B') of the Paleocene Fort Union Formation and associated CBM producing coal beds and zones (e.g., Big George) along the western part of the Powder River Basin, Wyoming and Montana. Adapted from Flores and others (1999).

Figure 9. North-south cross section (A-A') of the Paleocene Fort Union Formation and associated CBM producing coal beds and zones (e.g.,Wyodak-Anderson) along the eastern part of the Powder River Basin, Wyoming. Adapted from Flores and others (1999).

Figure 10. East-west cross section (D-D and') of the Paleocene Fort Union Formation and associated CBM producing coal beds and zones (e.g., Wyodak-Anderson) along the south-central part of the Powder River Basin, Wyoming. Adapted from Flores and others (1999).

Figure 11. East-west cross section (C-C') of the Paleocene Fort Union Formation and associated CBM producing coal beds and zones (e.g., Wyodak-Anderson) along the north-central part of the Powder River Basin, Wyoming. Adapted from Flores and others (1999). 
Figure 12. Map showing the thickness of the overburden or rocks above the WyodakAnderson coal zone in the Powder River Basin. Adapted from Ellis and others (1999).

Figure 13. Map showing the trend of historical CBM development from 1976 to 2000 along the eastern part of the Powder River Basin, Wyoming.

Figure 14. Graph showing the trends of CBM production from January, 1990 to October, 2000 in the Powder River Basin, Wyoming. Total gas production includes Federal, State, and Private leases (graph provided by Fred Crockett).

Figure 15. Graph showing the number of CBM producing wells from January 1990 to October, 2000 in the Powder River Basin, Wyoming (graph provided by Fred Crockett).

Figure 16. Graph showing the depth range of CBM producing wells from January 1990 to October, 2000 in the Powder River Basin, Wyoming (graph provided by Fred Crockett).

Figure 17. Graph showing the trends of co-produced water from January, 1990 to October, 2000 in the Powder River Basin, Wyoming. Total co-produced water includes Federal, State, and Private leases (graph provided by Fred Crockett).

Figure 18. Maximum modeled drawdown of groundwater in the Wyodak-Anderson coal zone from 1975-2015 in the eastern part of the Powder River Basin, Wyoming. Modified from Bureau of Land Management (1999).

Figure 19. Map showing the watersheds, creeks, and rivers in the Powder River Basin, Wyoming and Montana (map provided by Joe Meyer).

Figure 20. Map showing SAR values in the Powder River Basin, Wyoming (data from Rice and others, 2000).

Figure 21. Map showing locations of 18 coal mines in the Gillette coalfield along the eastern margin of the Powder River Basin.

Figure 22. Map showing the mine permit boundary and strip pits of the Jacobs Ranch Coal Company (map provided by Rob Livingston).

Figure 23. A photograph of the mine highwall in Jacobs Ranch strip pit 1 showing the Wyodak-Anderson coal zone in the lower part and overlying fluvial deposits (photograph provided by Rob Livingston).

Figure 24. Map showing the locations of CBM wells and pipeline infrastructure in the Dry Fork, Greater Black Thunder, and Little Thunder CBM fields southeast of Wright, Wyoming (map provided by Tom Doll).

Figure 25. Map showing locations of CBM, oil, gas, and coal wells between Wright and Jacobs Ranch-Black Thunder coal mines. Cross section (A-B') is shown in Figure 26 (map provided by Al Ochs). 
Figure 26. East-west cross section (A-B) showing the vertical and lateral stratigraphic variations of the CBM-producing Wyodak-Anderson coal zone and related fluvial deposits of the Fort Union Formation from Jacobs Ranch coal mine to south of Wright (cross section provided by Al Ochs).

Figure 27. Map showing the net coal thickness isopach of the Wyodak-Anderson coal zone in the Powder River Basin, Wyoming and Montana. Adapted from Ellis and others (1999).

Figure 28. Map showing the net coal thickness isopach of coal beds deeper than the Wyodak-Anderson coal zone in the Powder River Basin, Wyoming and Montana (map provided by Margaret Ellis).

Figure 29. Map showing the thickness of the overburden or rocks above the coal beds deeper than the Wyodak-Anderson coal zone in the Powder River Basin (map provided by Margaret Ellis).

Figure 30. A photograph of a truck mounted rig used by gas developers for shallow drilling of the Fort Union coal beds in the Powder River Basin.

Figure 31. Map showing the network of pipelines and locations of producing wells in the Gap gas gathering complex of Bear Paw Energy (map provided by Pierce Norton).

Figure 32. Map showing the major (16, 20, and 24 inches in diameter) pipeline infrastructure in the Powder River Basin, Wyoming and Montana (map provided by Pierce Norton).

\section{List of Tables}

Table 1. Chemical composition of co-produced water in the Powder River Basin, Wyoming. Data from Rice and others (2000). 


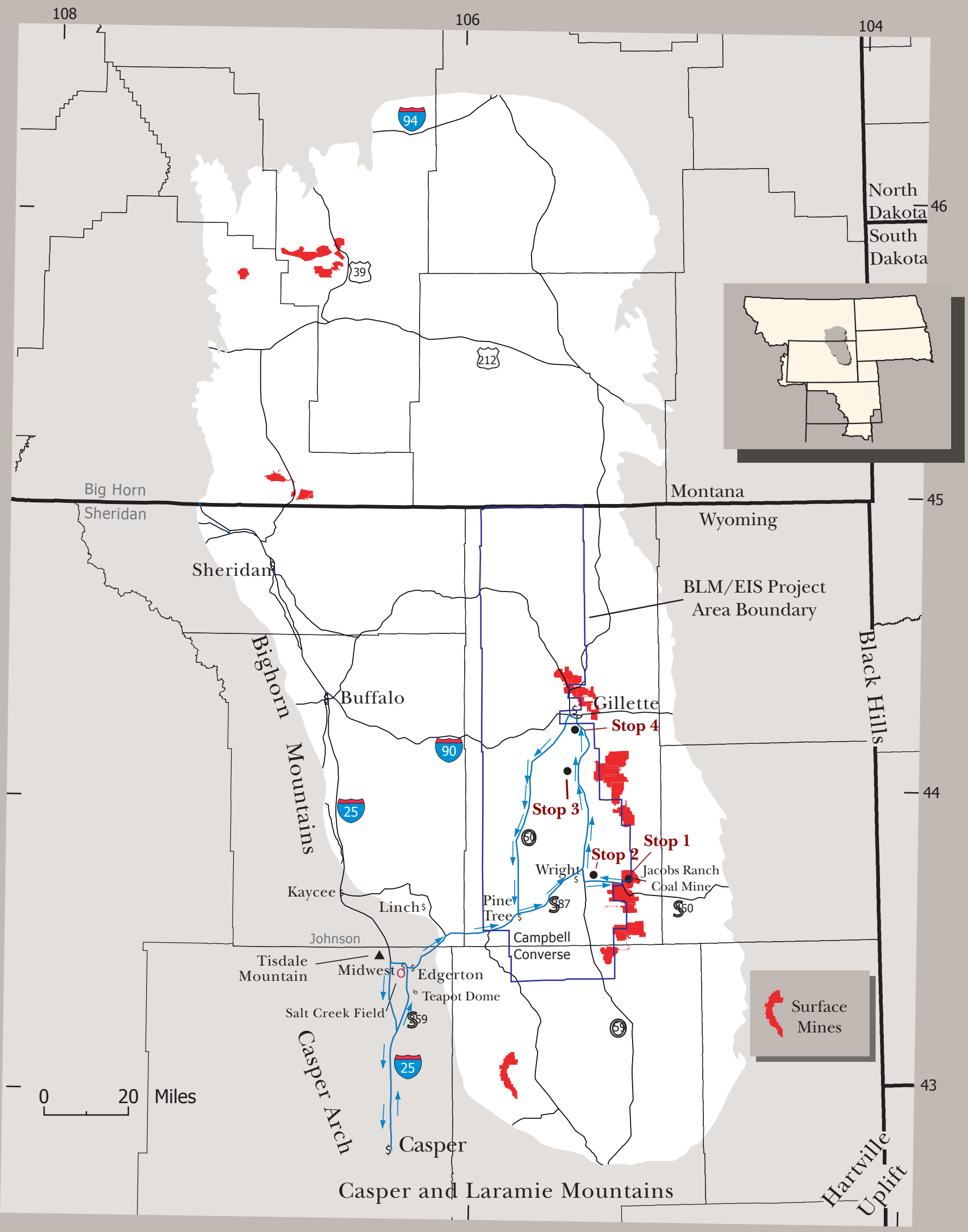

Figure 1 

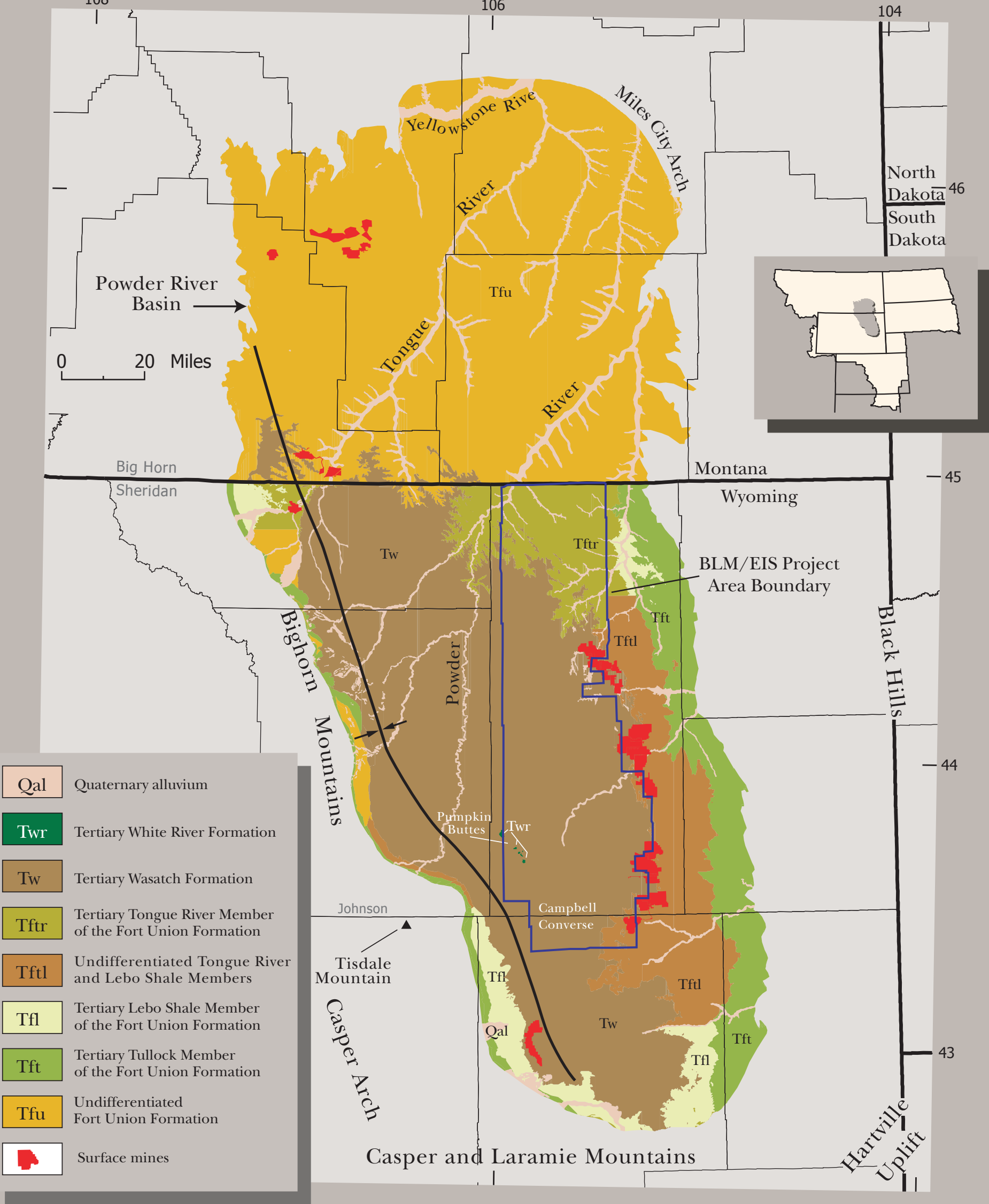

Figure 2 


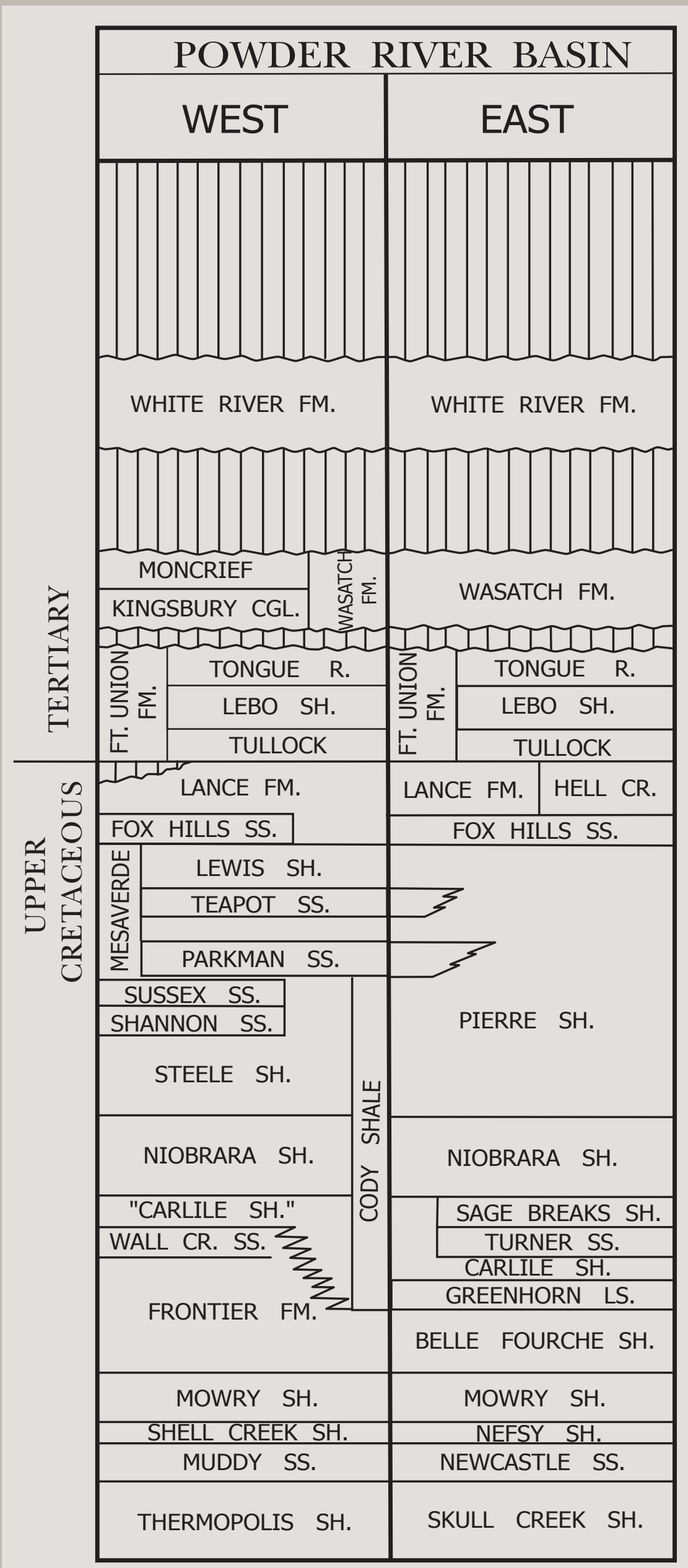

Figure 3 


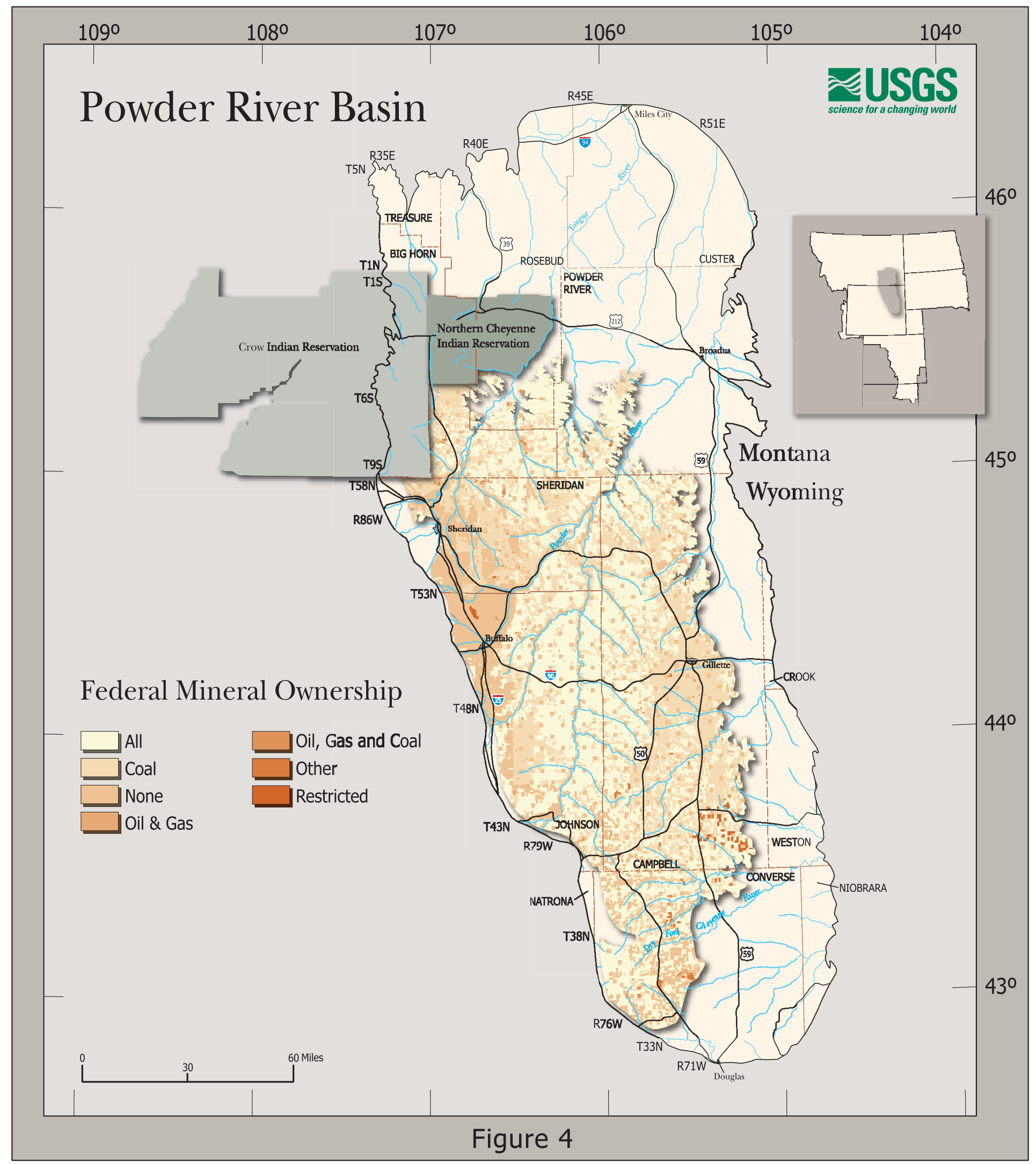




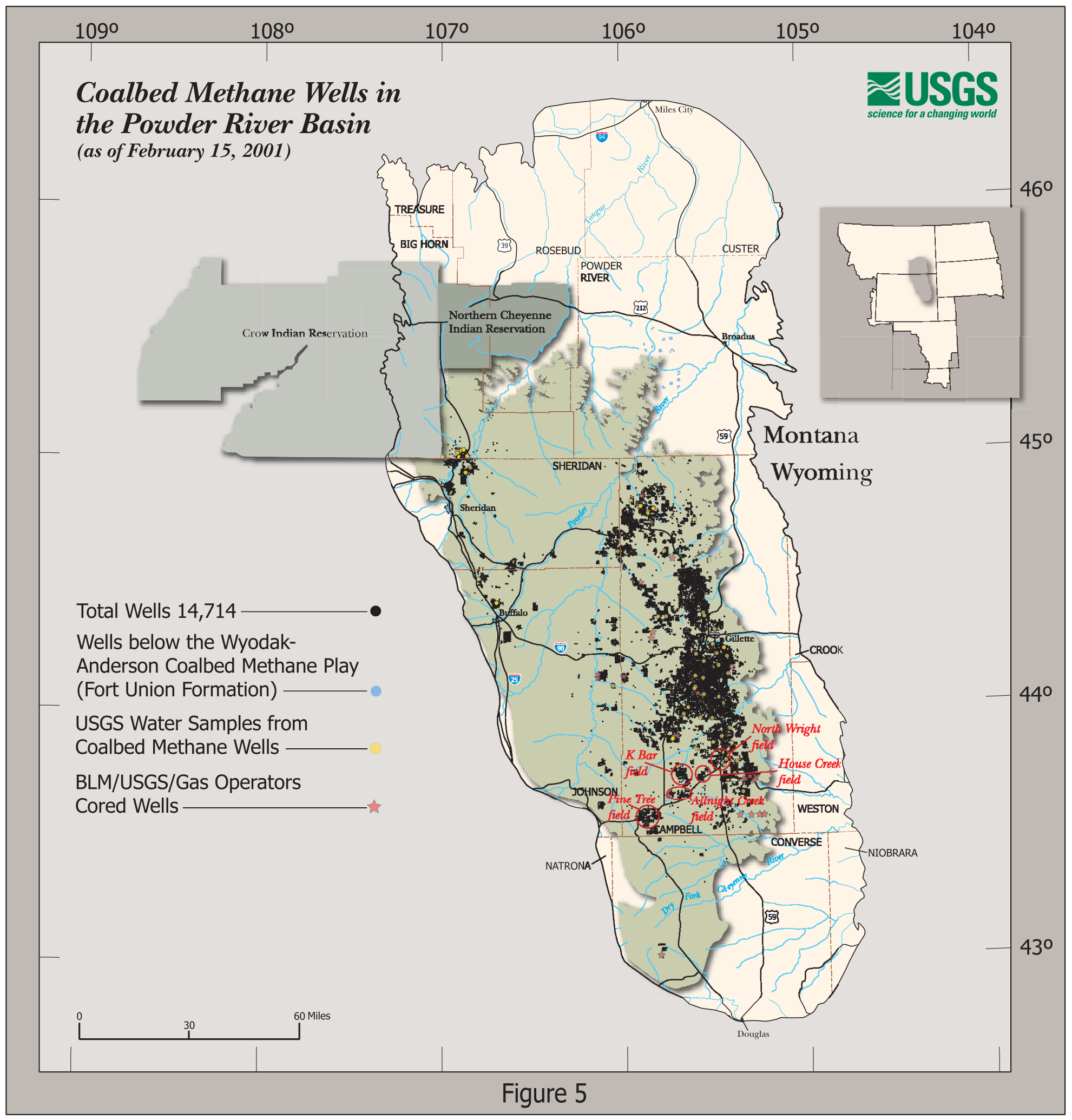




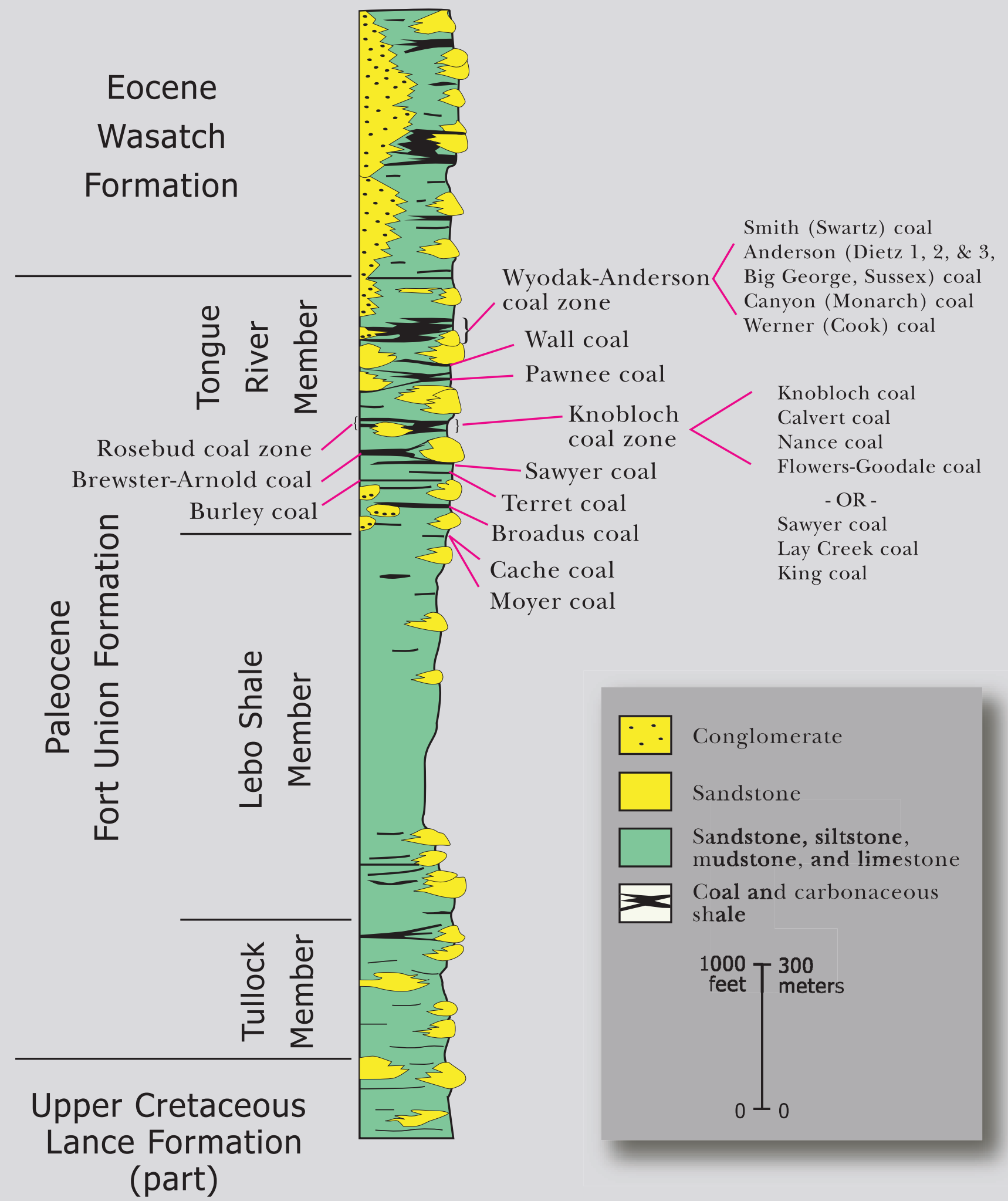




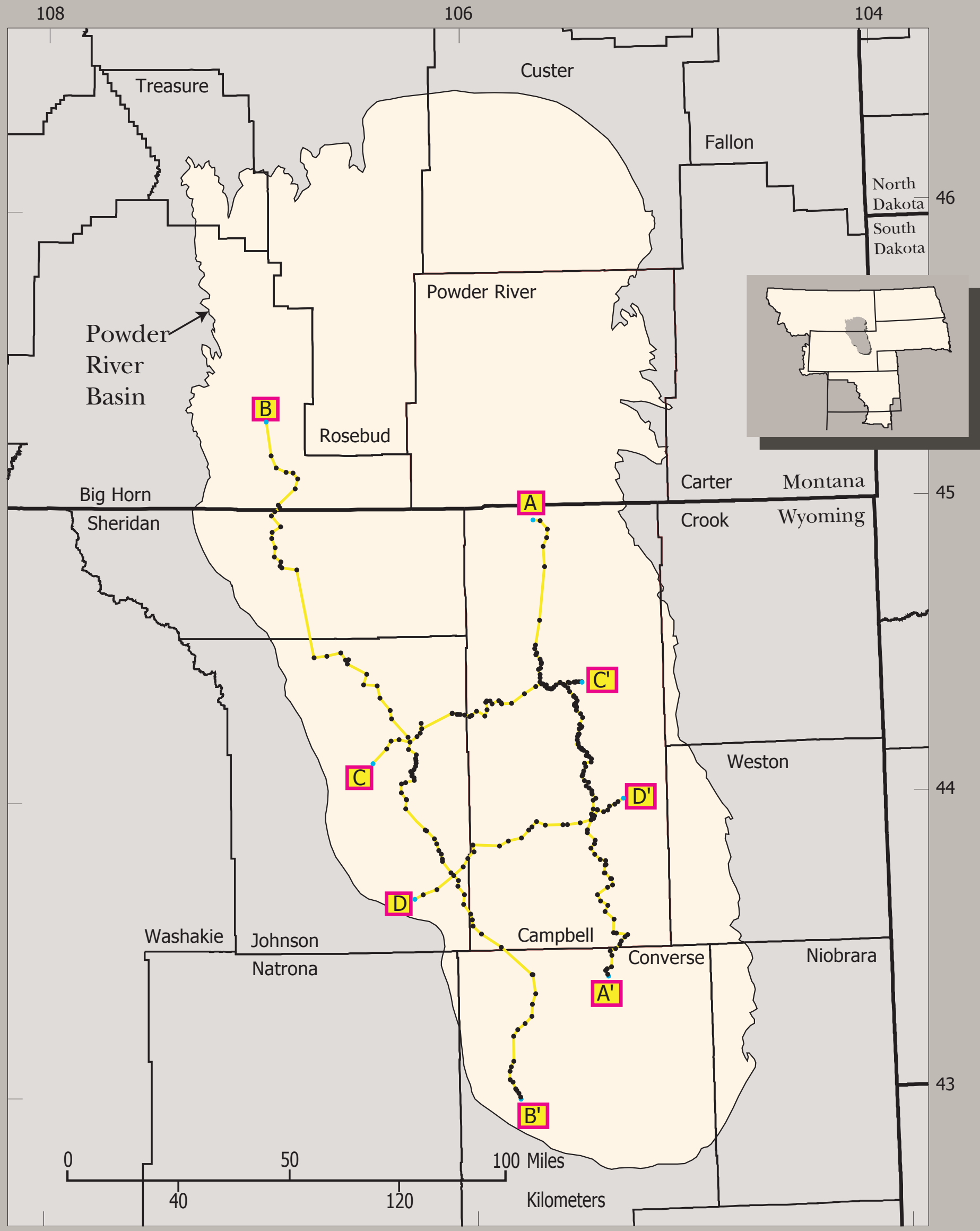

Figure 7 
North

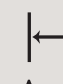
A
114.78 Miles

South $\mathrm{A}^{\prime}$

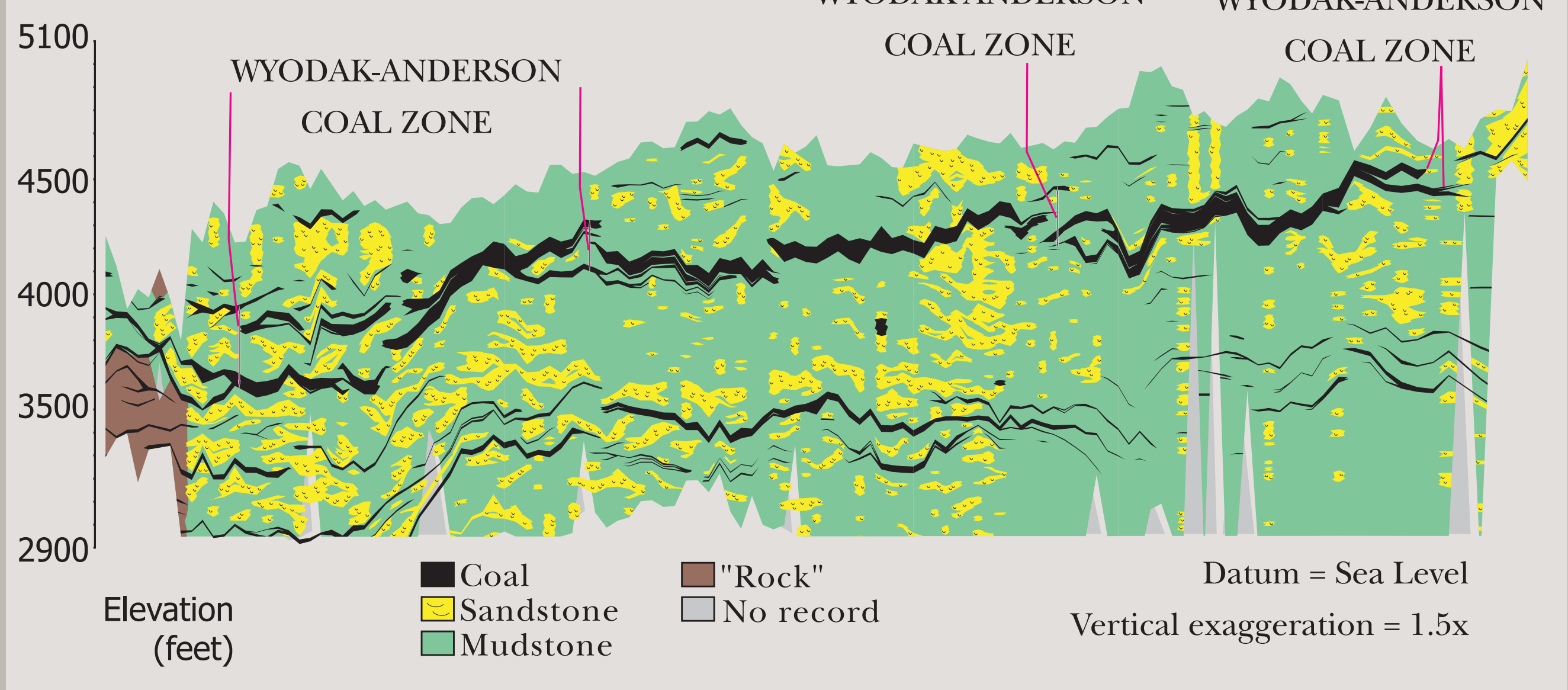

Figure 8 


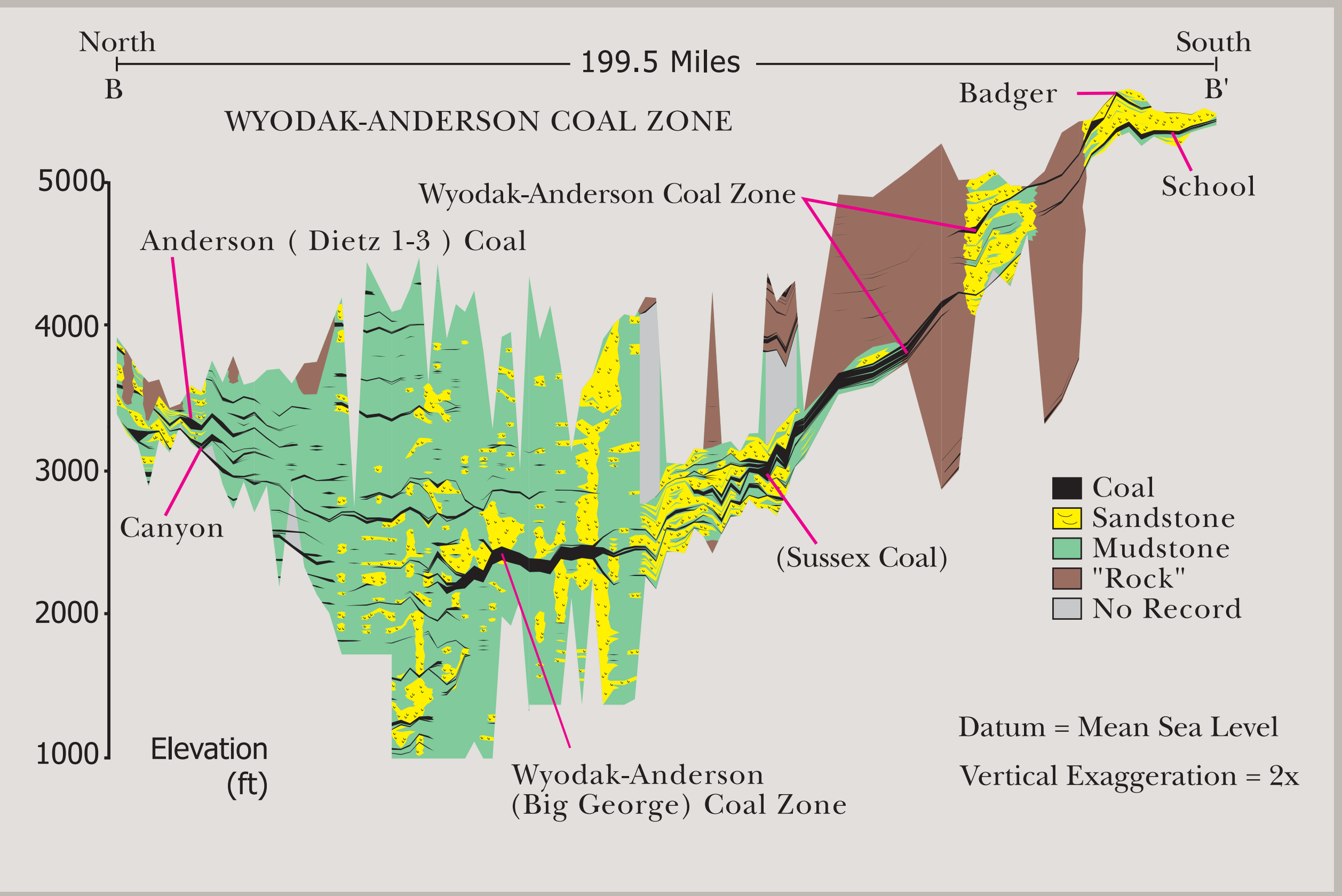

Figure 9 


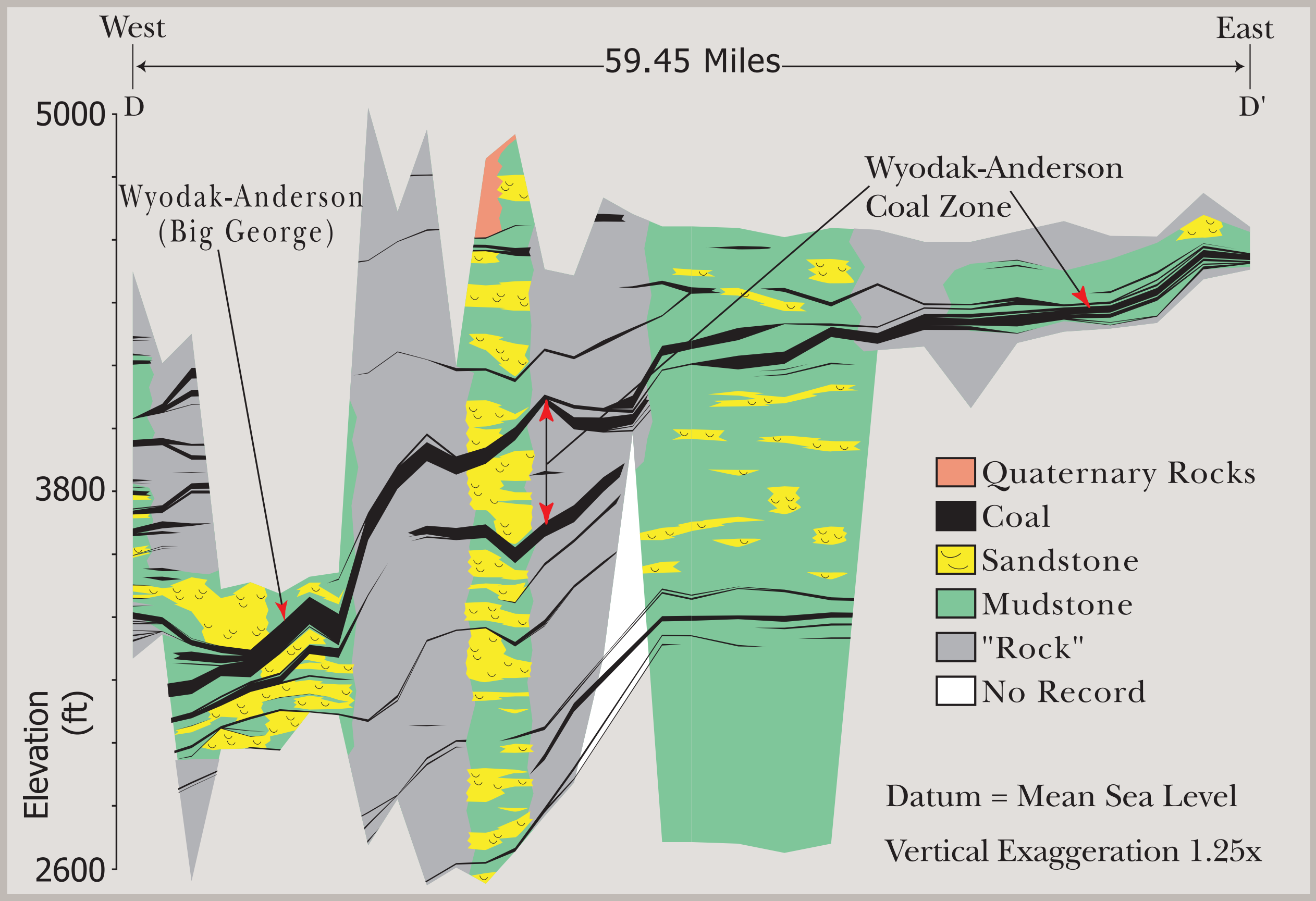

Figure 10 


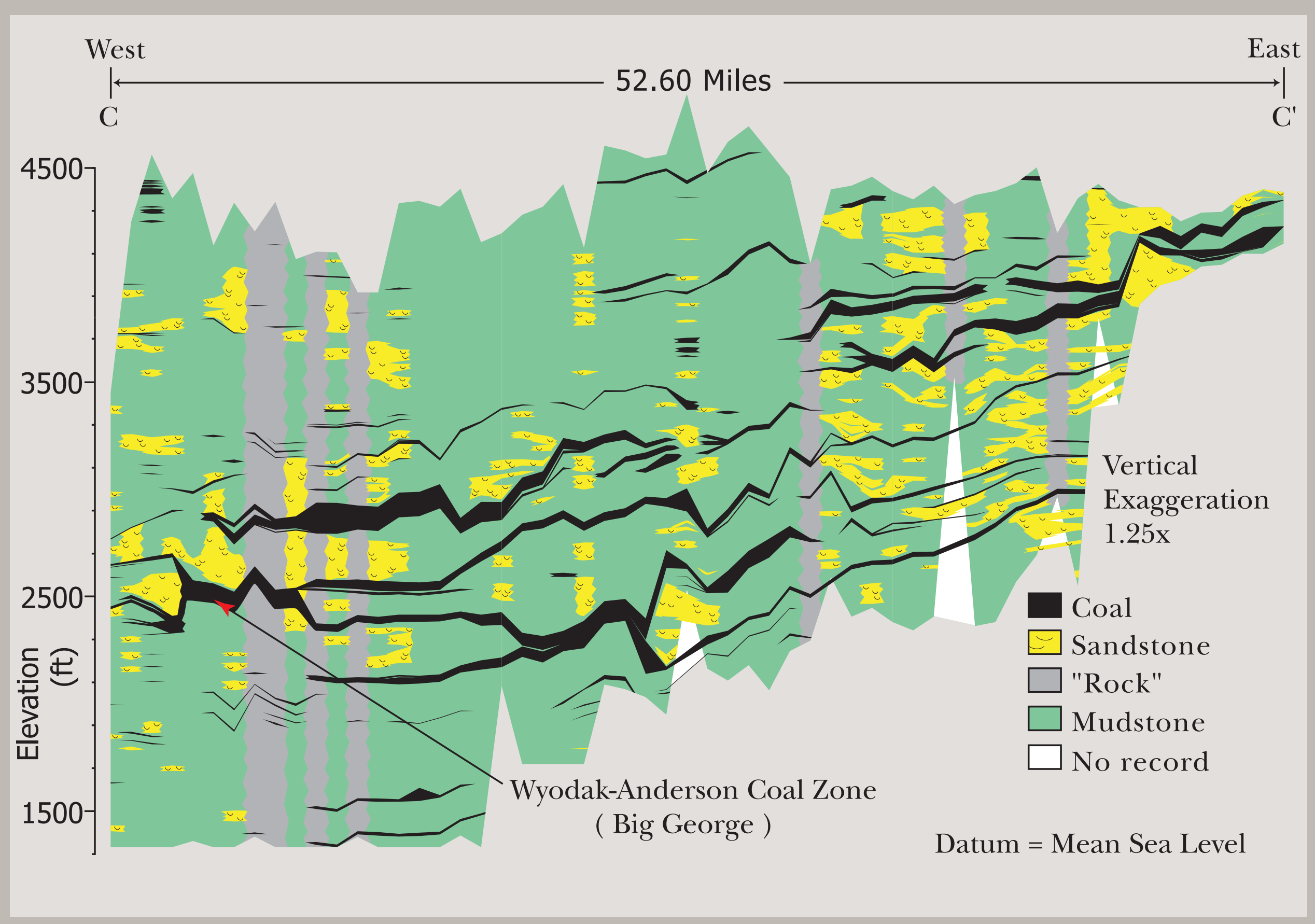

Figure 11 


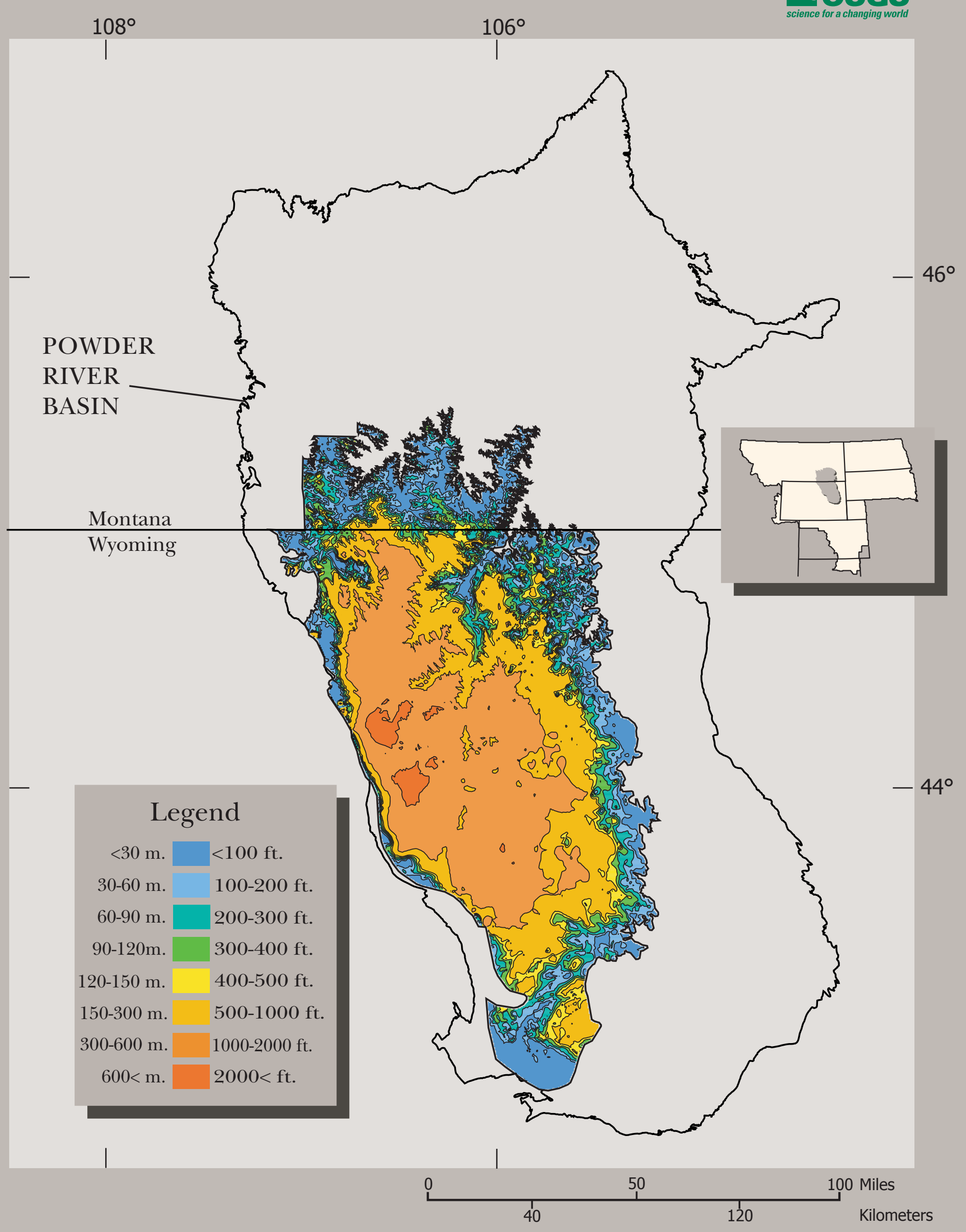

Figure 12 


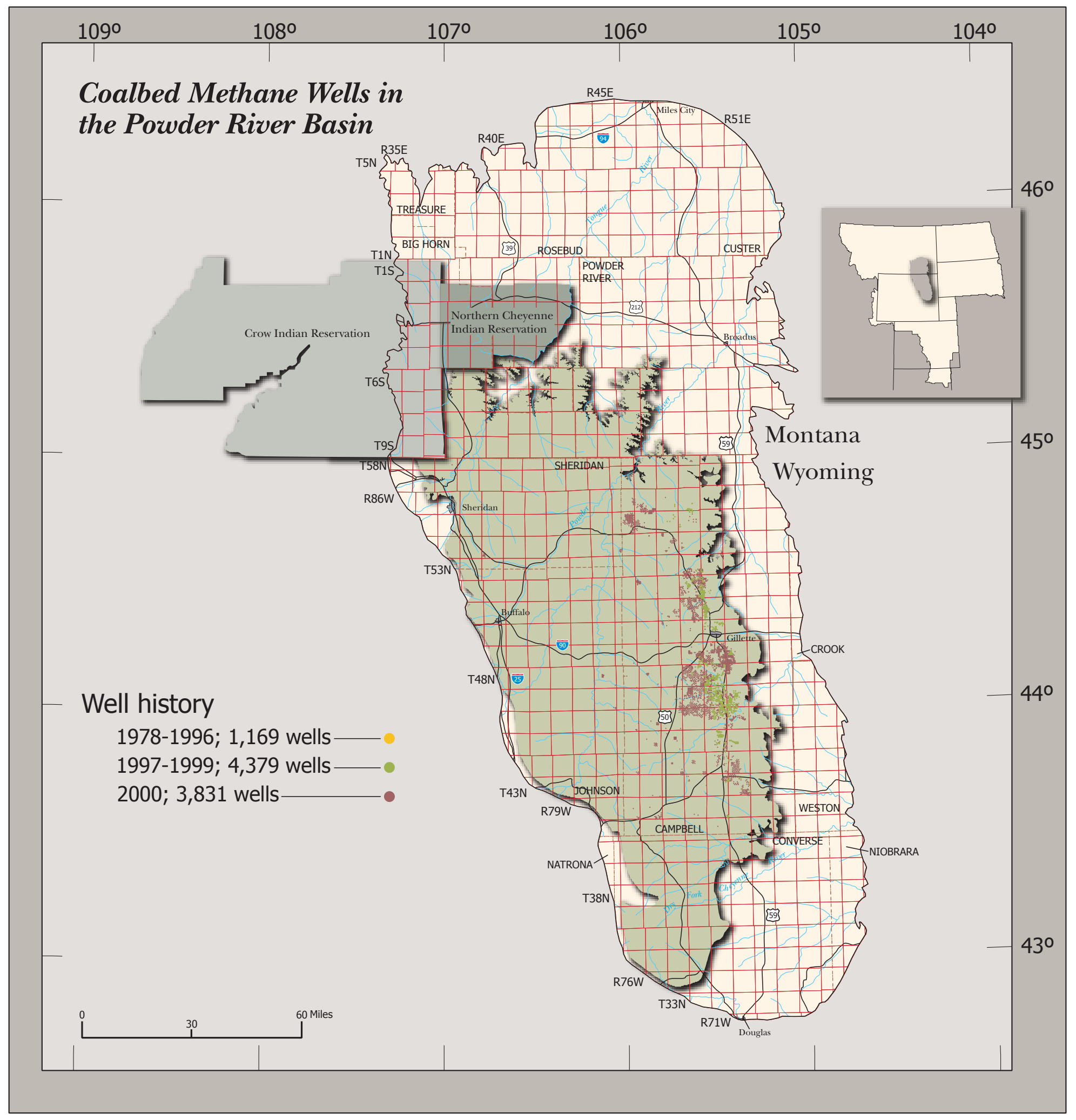




\section{₹USGS}

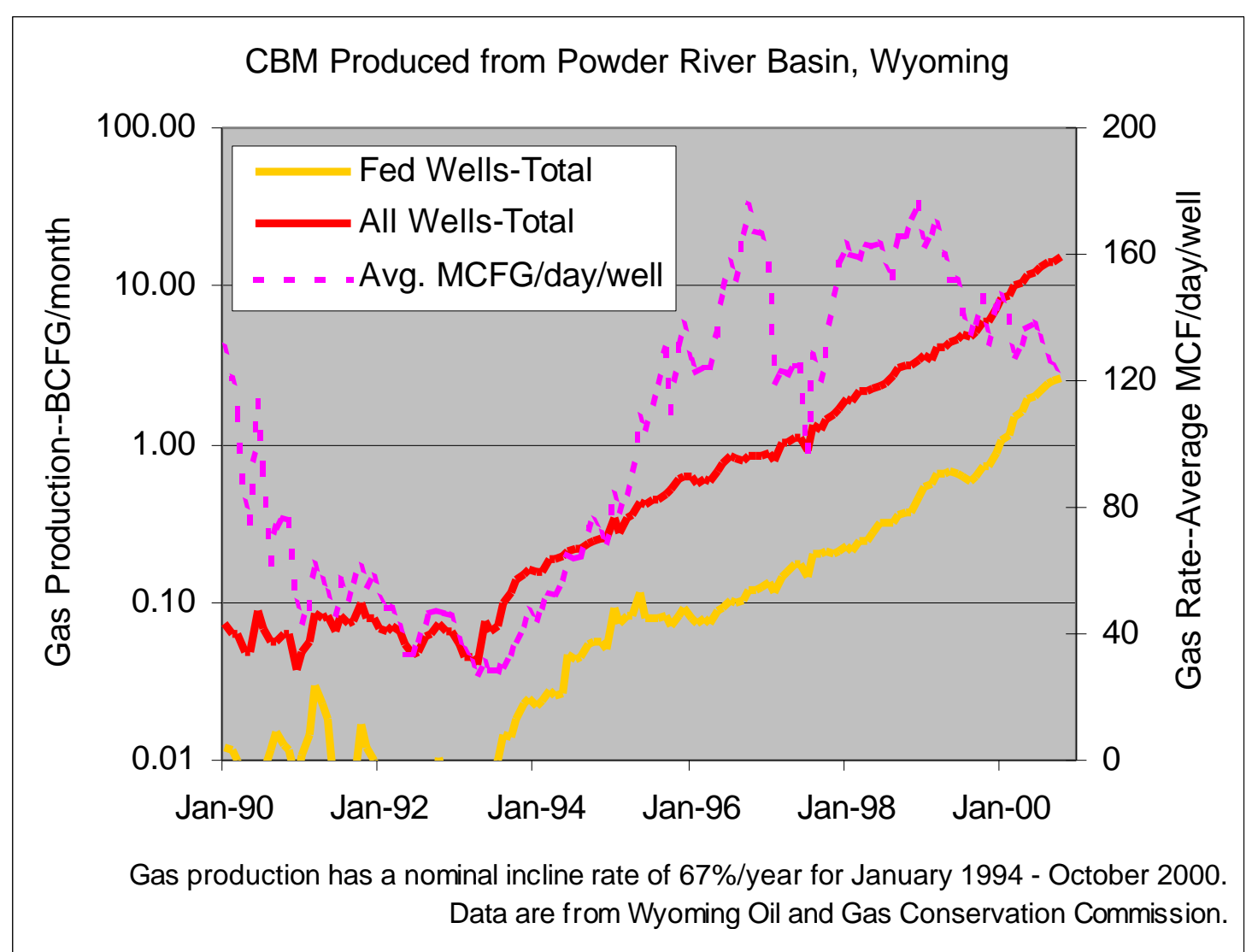

Figure 14 


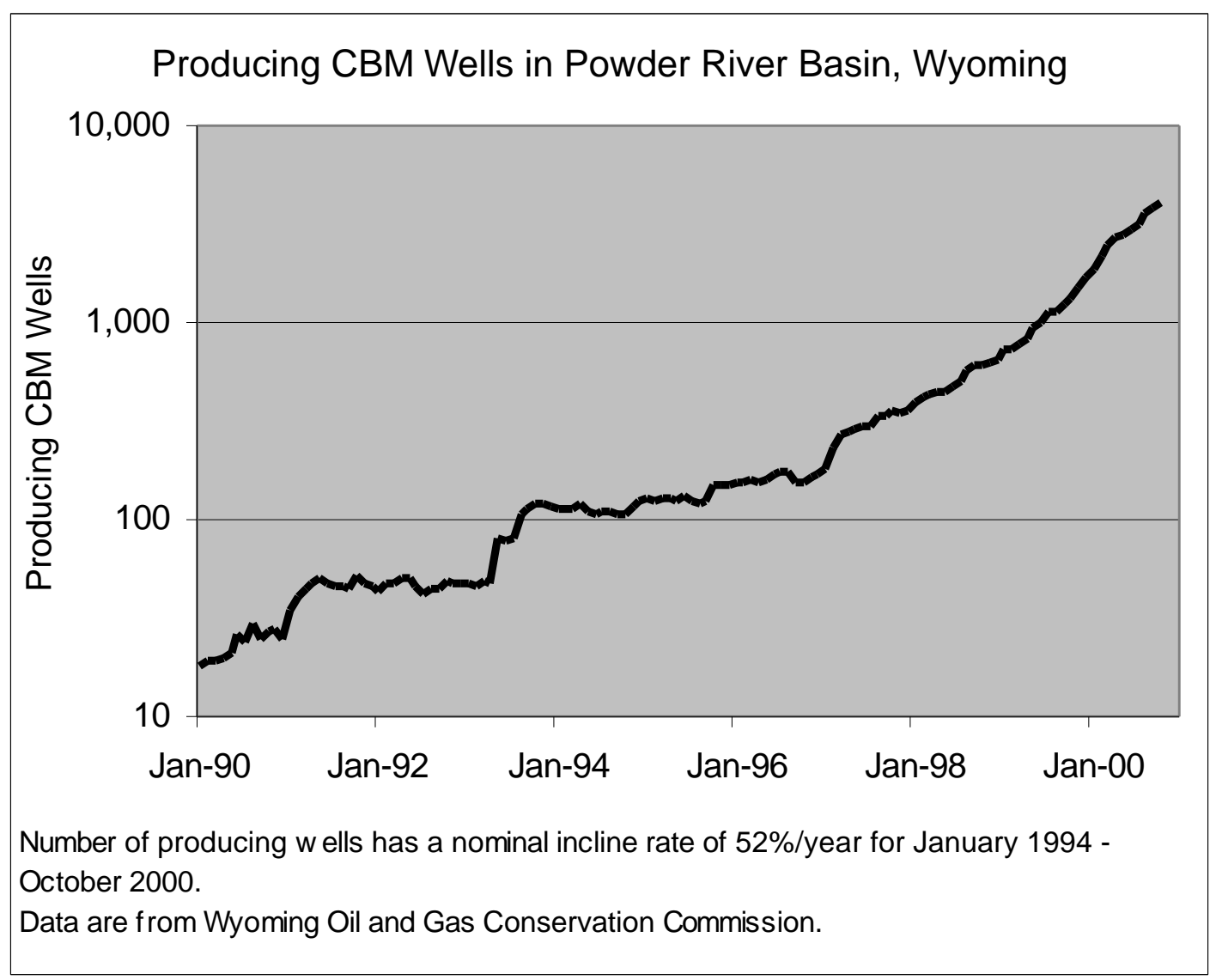

Figure 15 


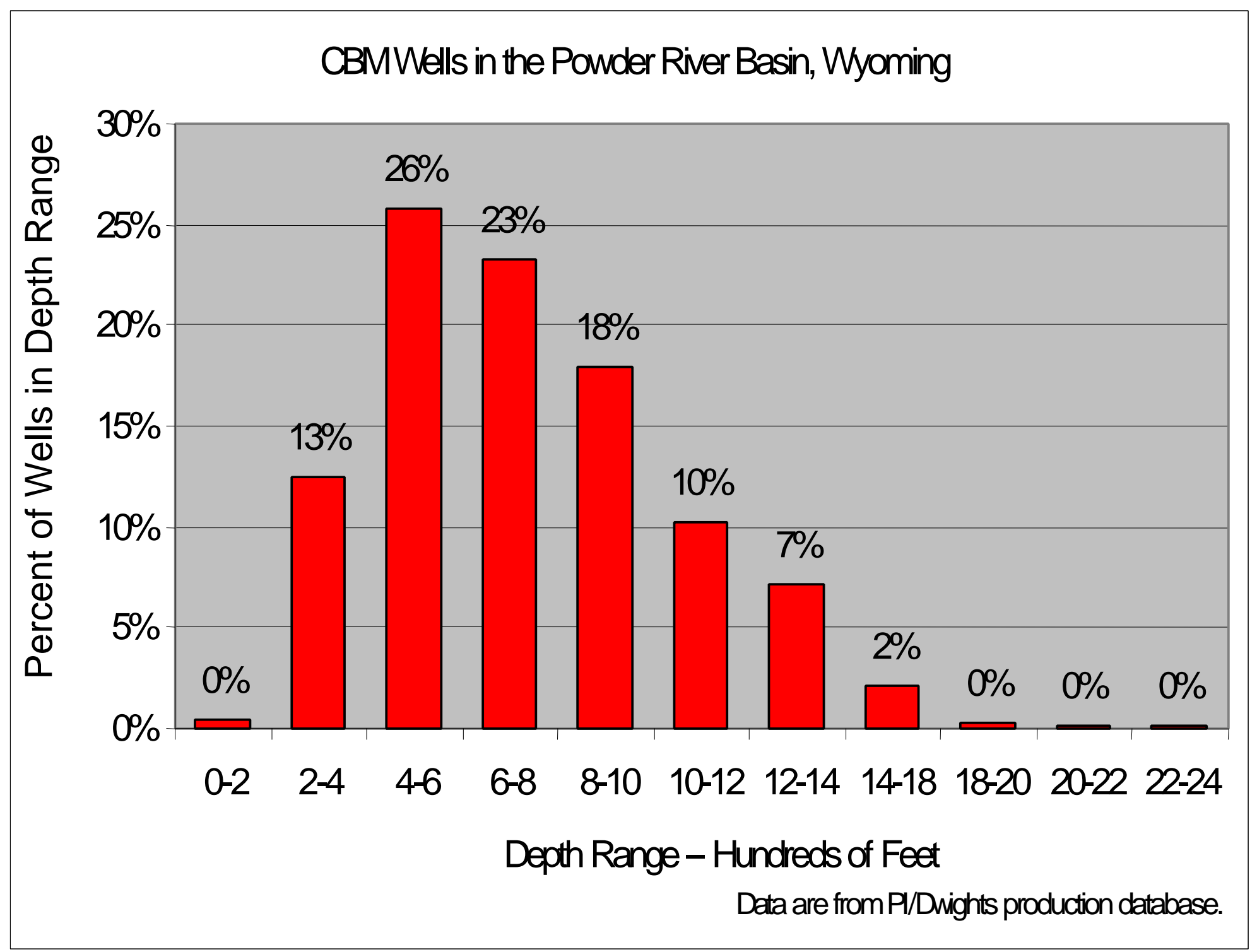

Figure 16 
Water Produced from Powder River Basin, Wyoming

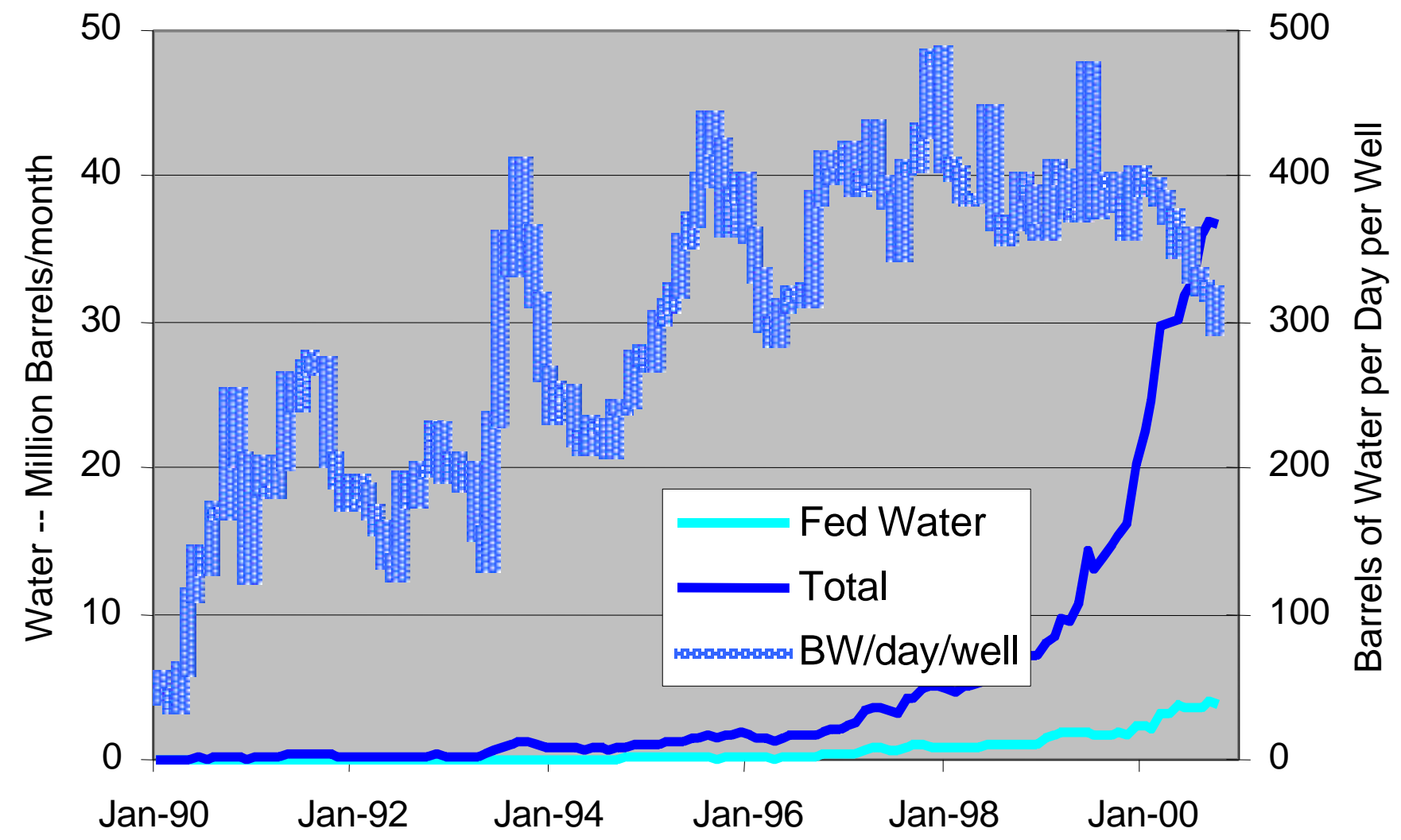

Water production has a nominal incline rate of 56\%/year for January 1994 - October 2000. Data are from WOGCC.

Figure 17 


\section{‡USGS \\ science for a changing world}

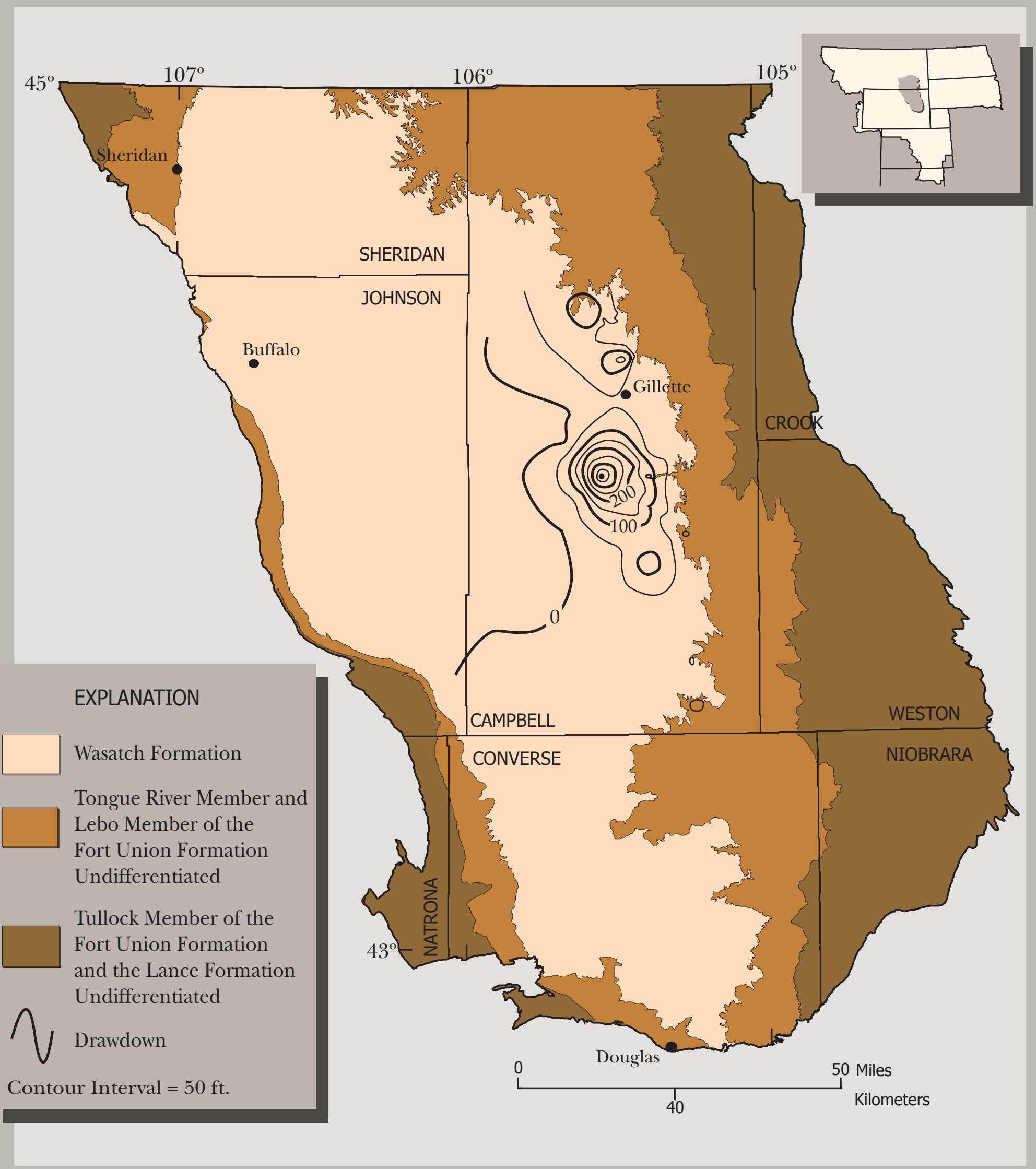

Figure 18 


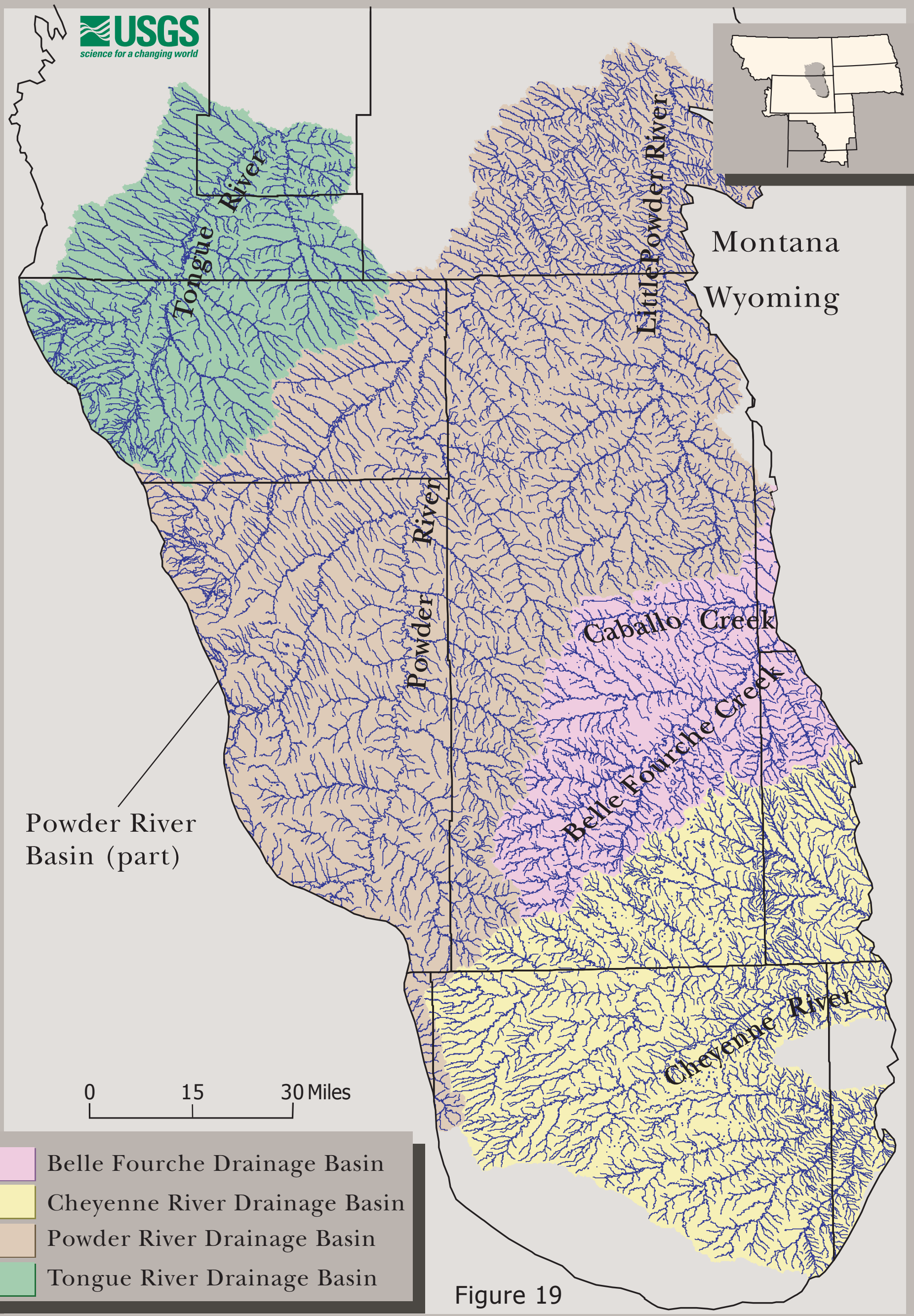




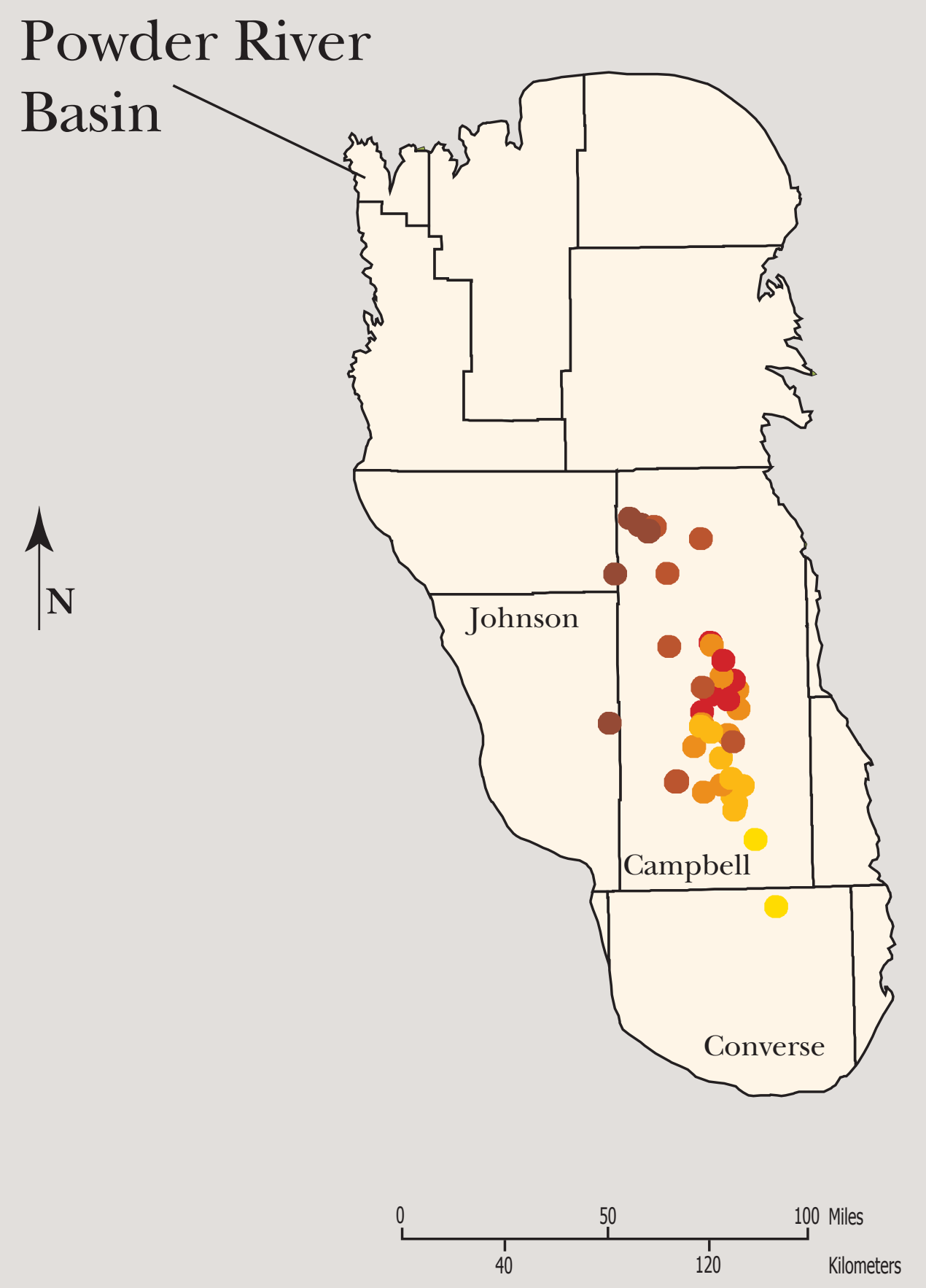

Powder River

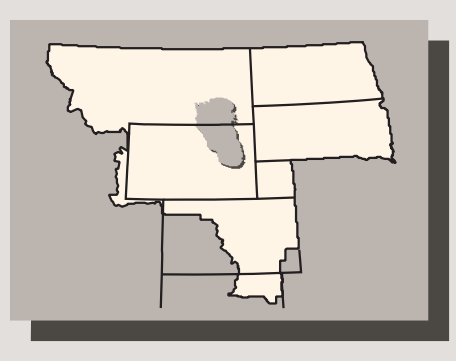

Sodium Absorption Ratio

$$
\begin{aligned}
\mathrm{mg} / \mathrm{L} \\
0-6.0 \\
6.1-6.9 \\
7.0-7.9 \\
\bullet \quad 8.0-8.9 \\
\cdot 9.0-21 \\
\cdot 22-31.7
\end{aligned}
$$




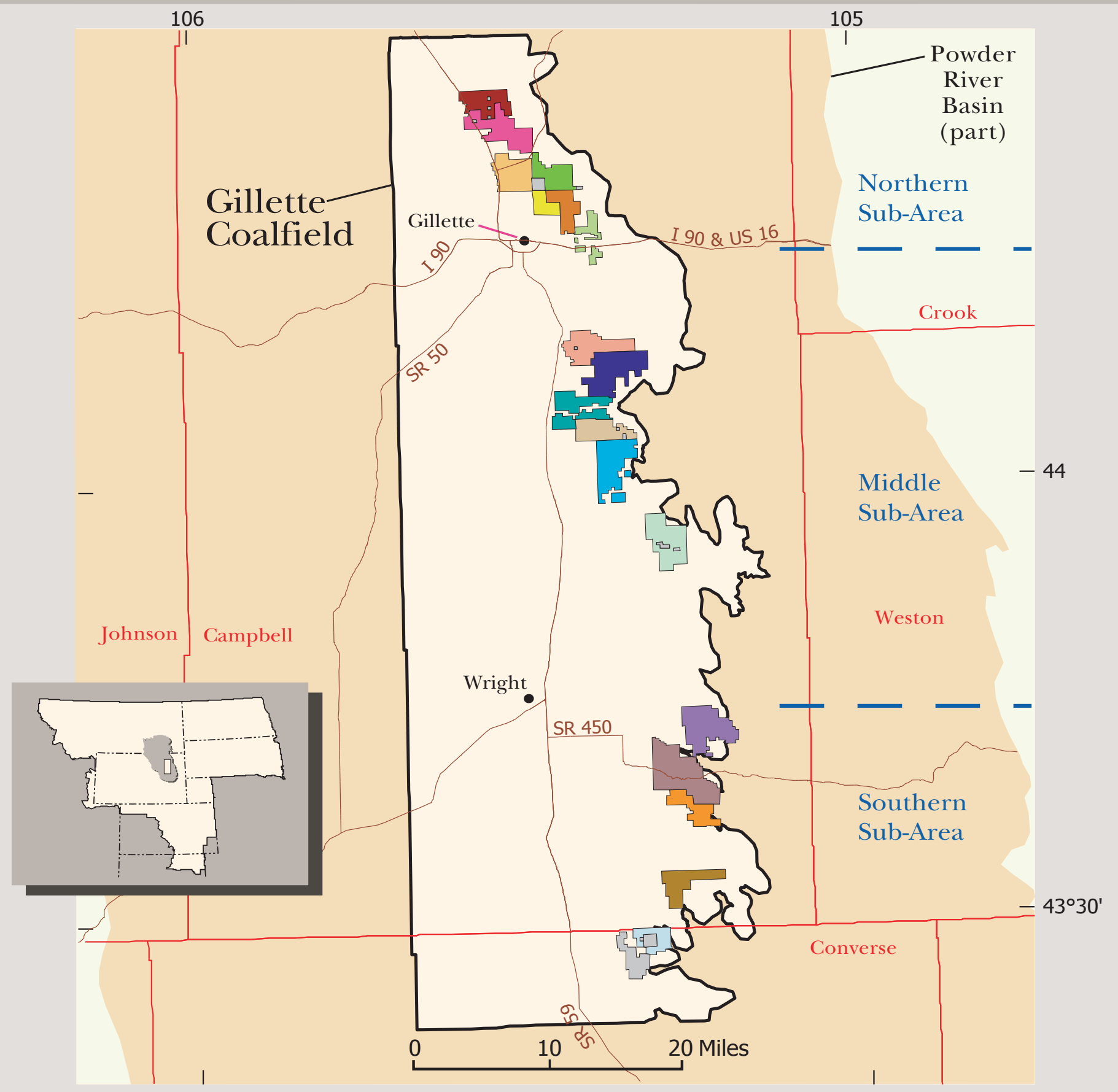

\section{Coal Mines}

or Lease Areas

Buckskin

$\square$ Rawhide

$\square$ Dry Fork

$\square$ Eagle Butte

$\square$ Fort Union

$\square$ Clovis Point

$\square$ Wyodak

$\square$ Rocky Butte

Caballo

$\square$ Belle Ayr

$\square$ Caballo Rojo

$\square$ Cordero

$\square$ Coal Creek

$\square$ Jacob's Ranch

$\square$ Black Thunder

$\square$ Rochelle

$\square$ North Antelope

$\square$ Antelope

BLM or state lease

Figure 21 
JACOBSRANCH COAL COMPANY is Nit

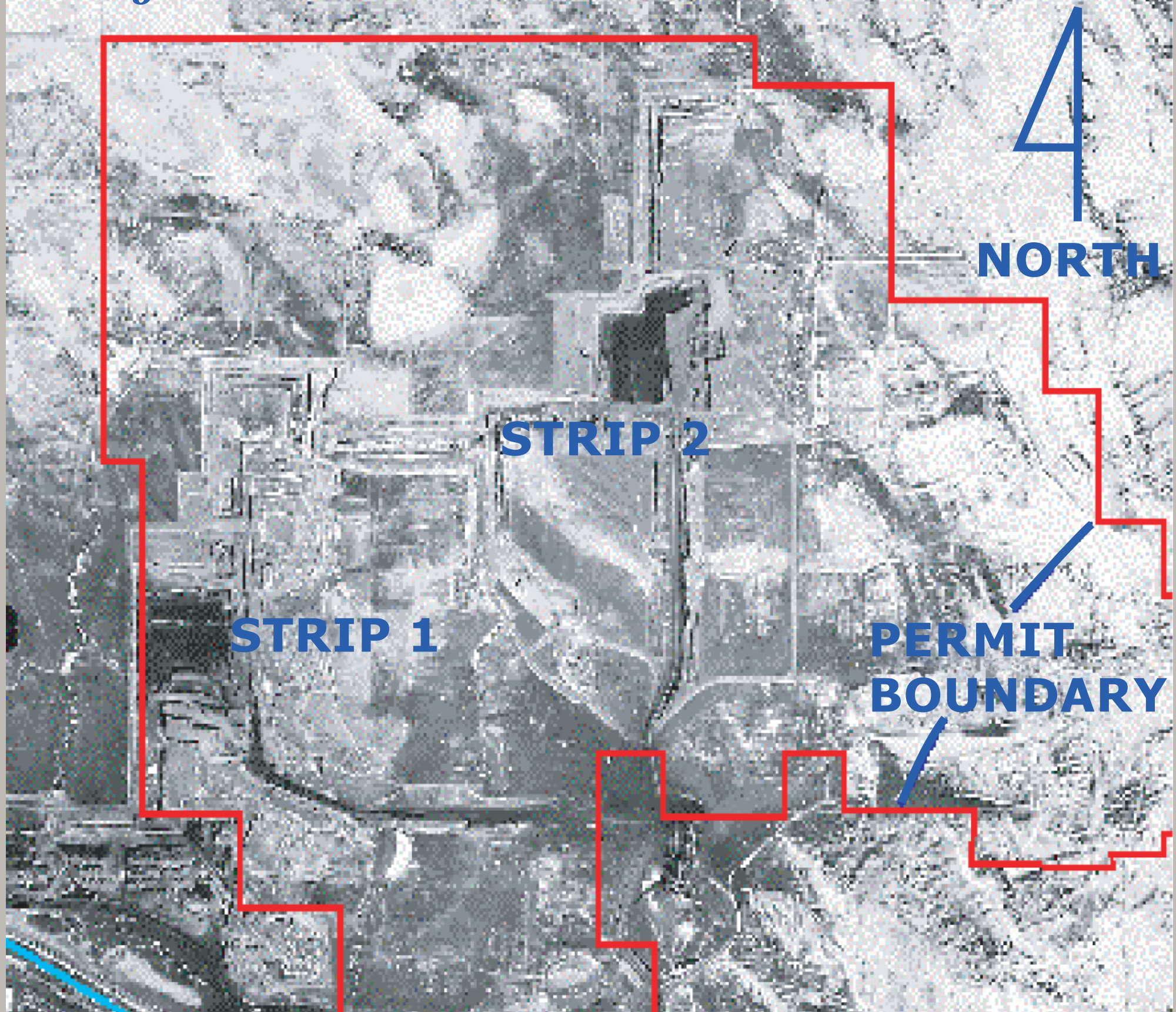

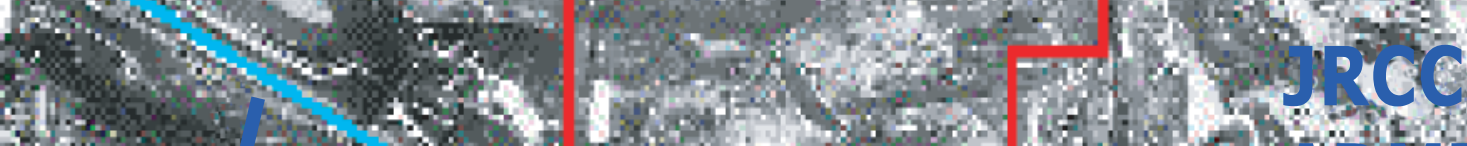

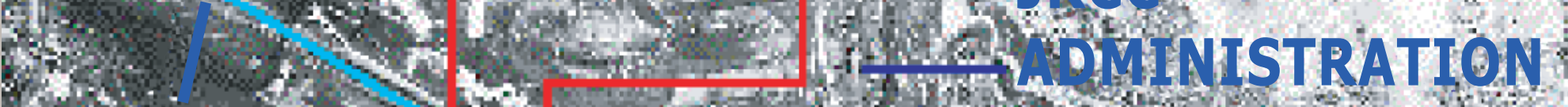

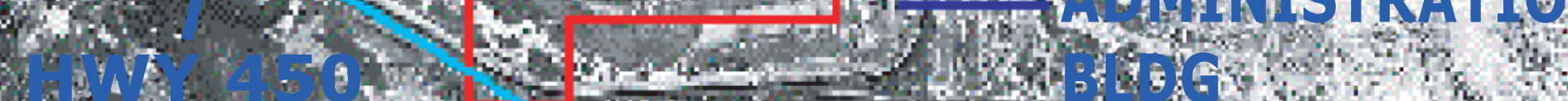

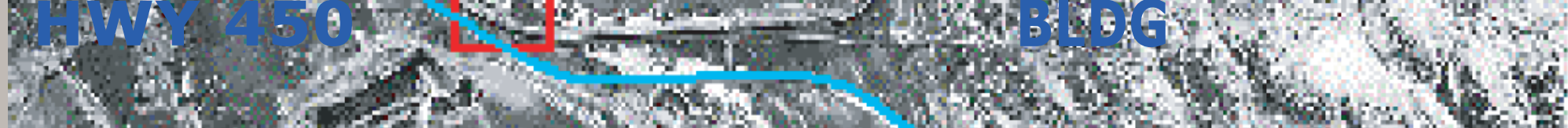

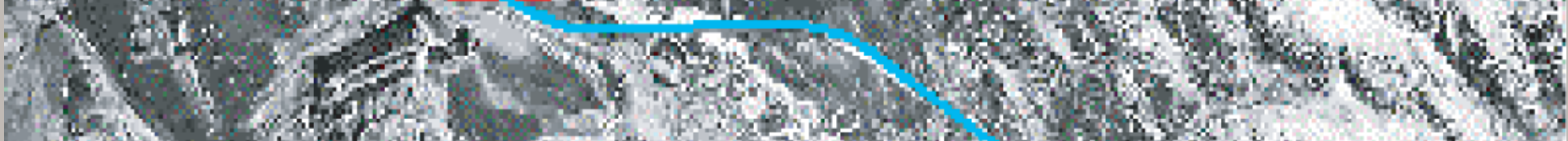

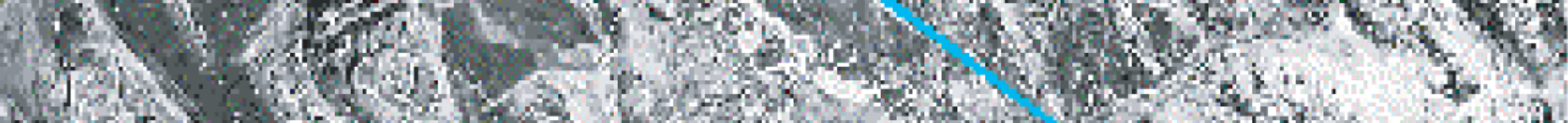

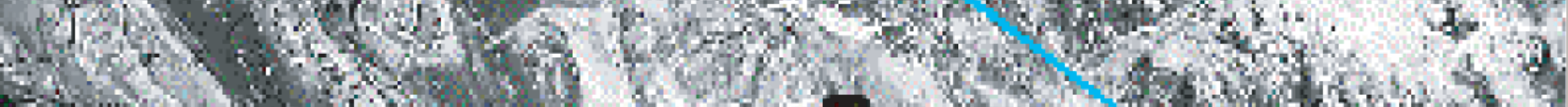

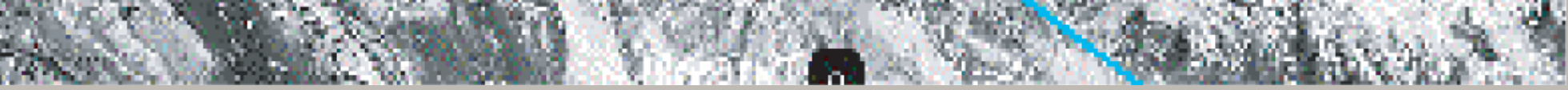




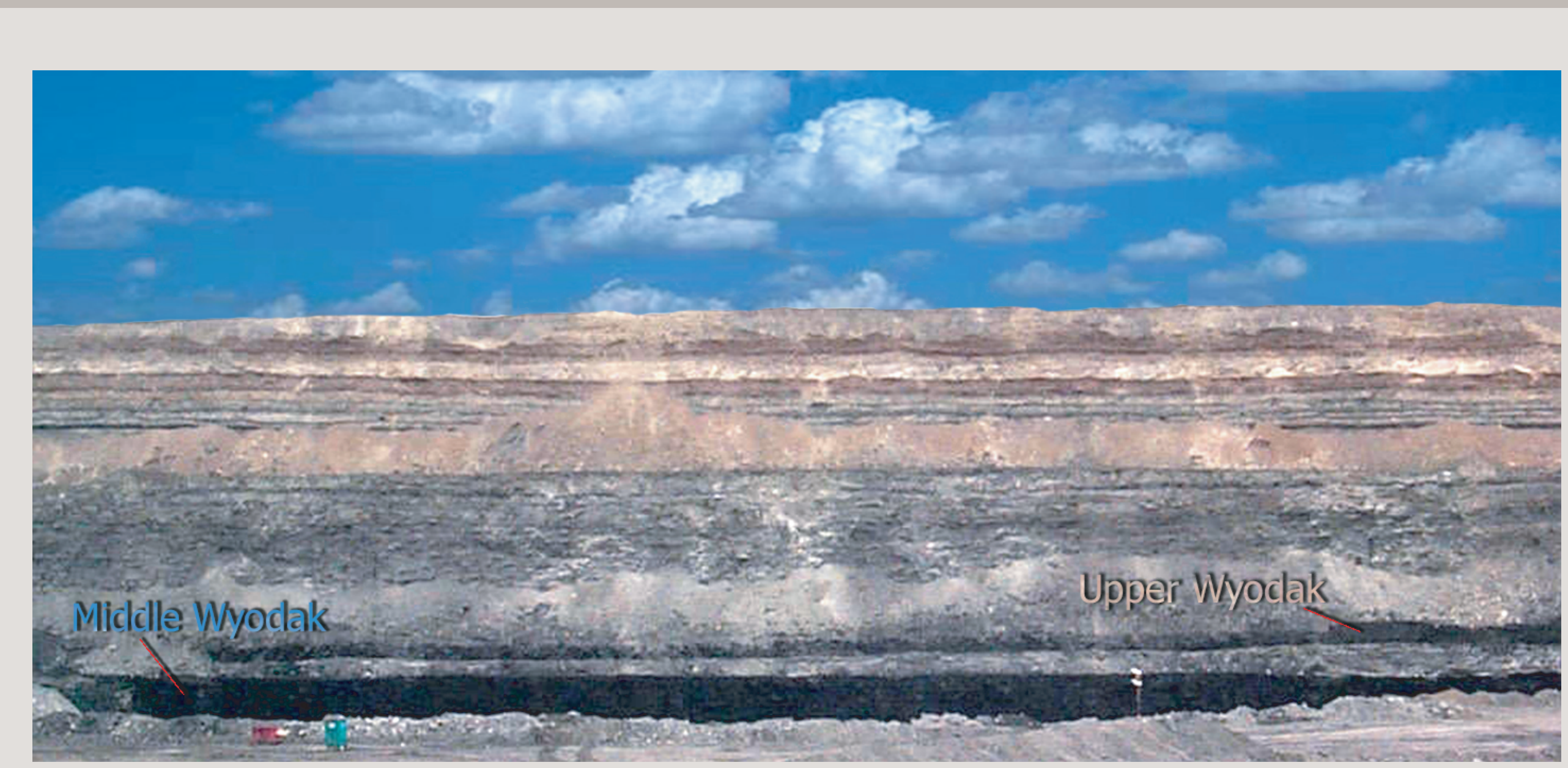

Figure 23 


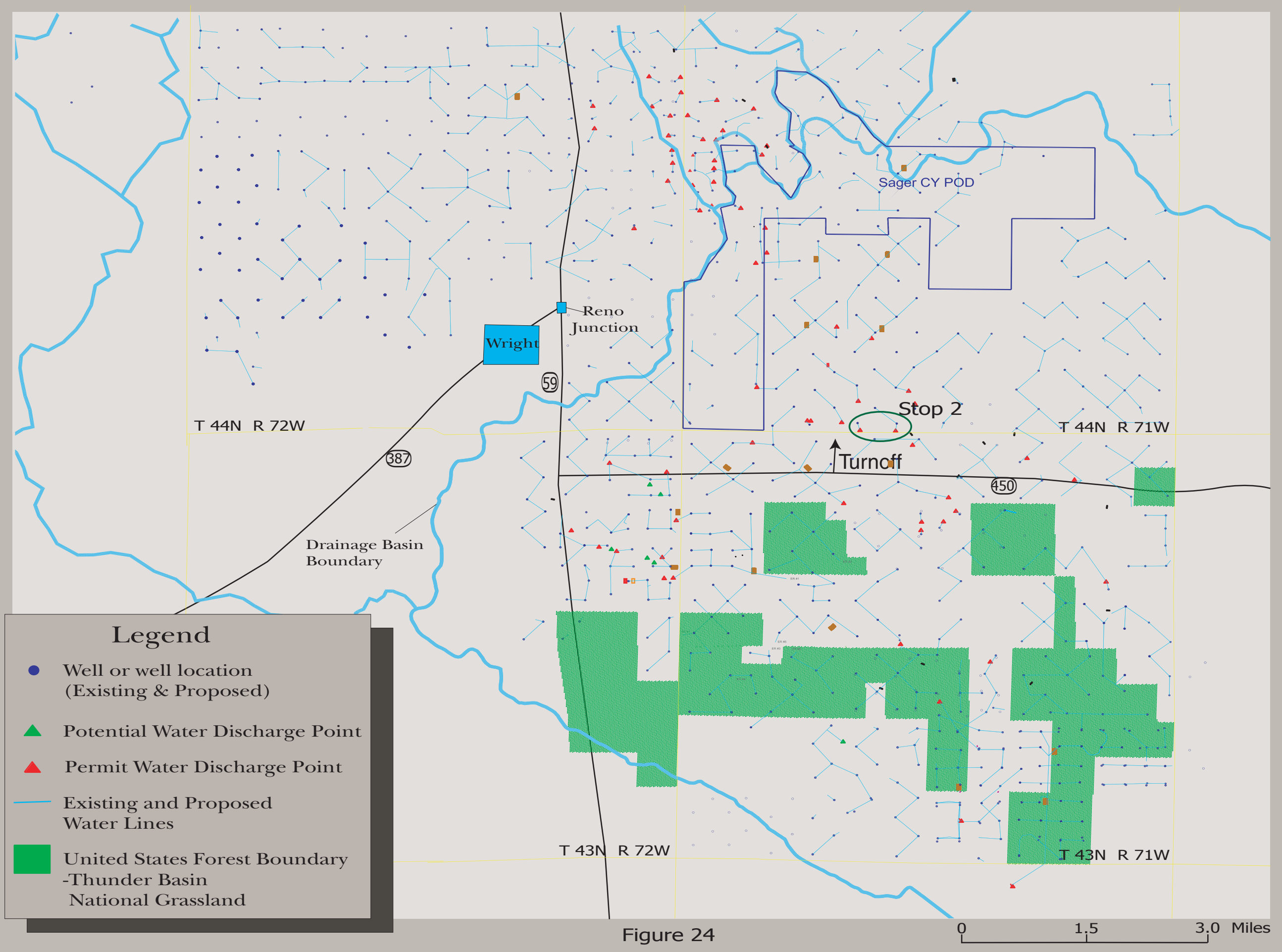




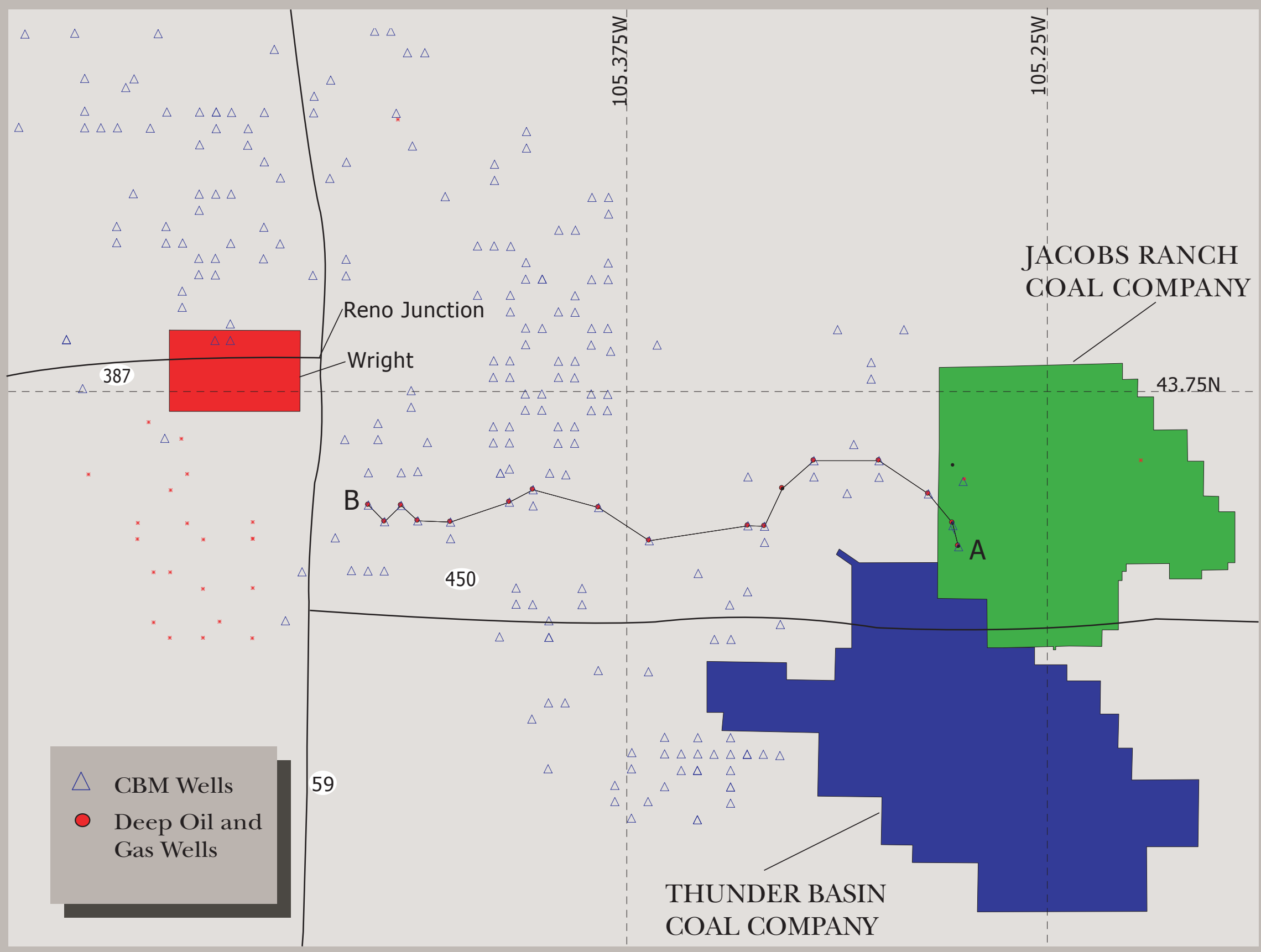

O $\quad 1_{i} 5 \quad 3,0$ Miles

Figure 25 


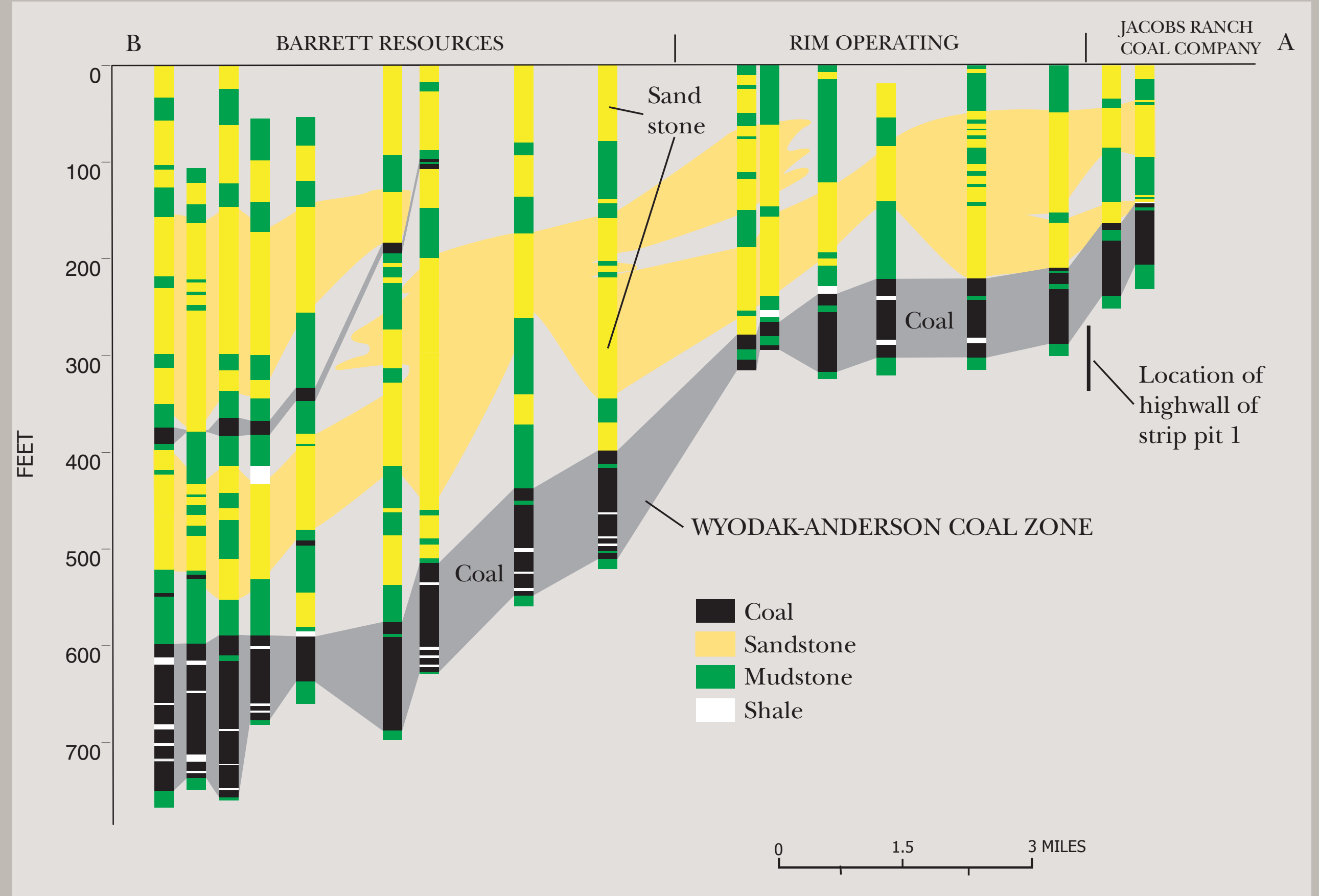

Figure 26 


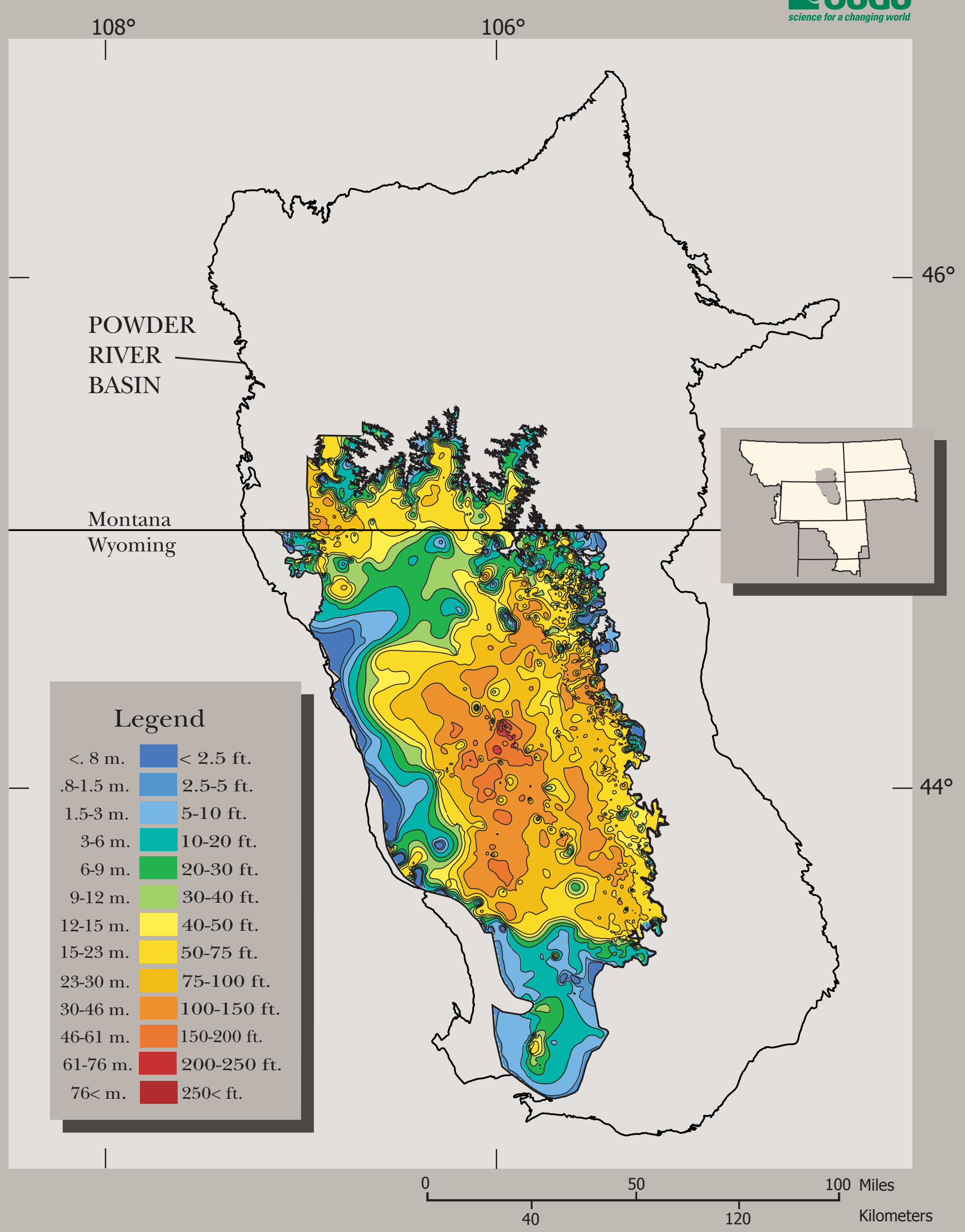

Figure 27 


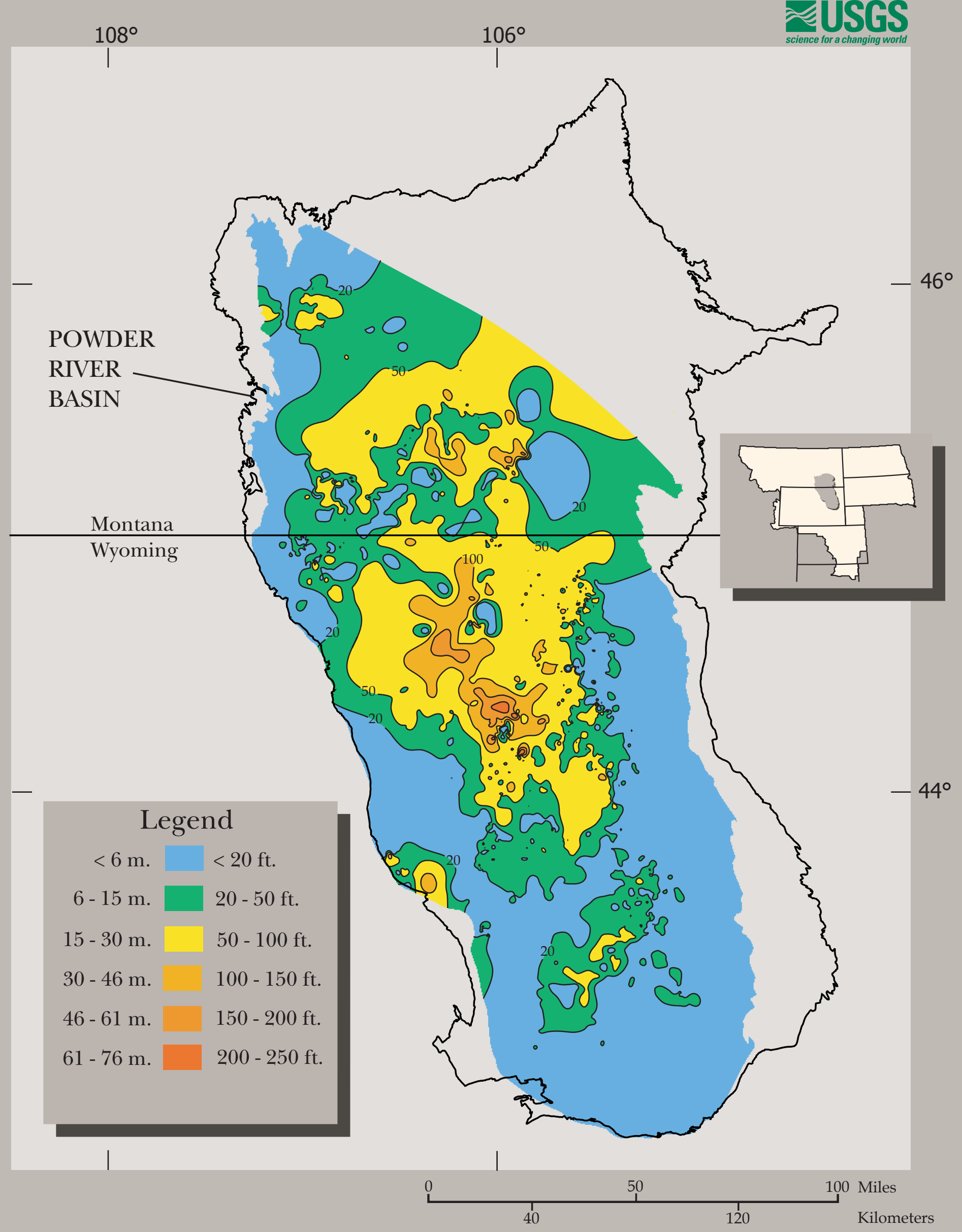

Figure 28 


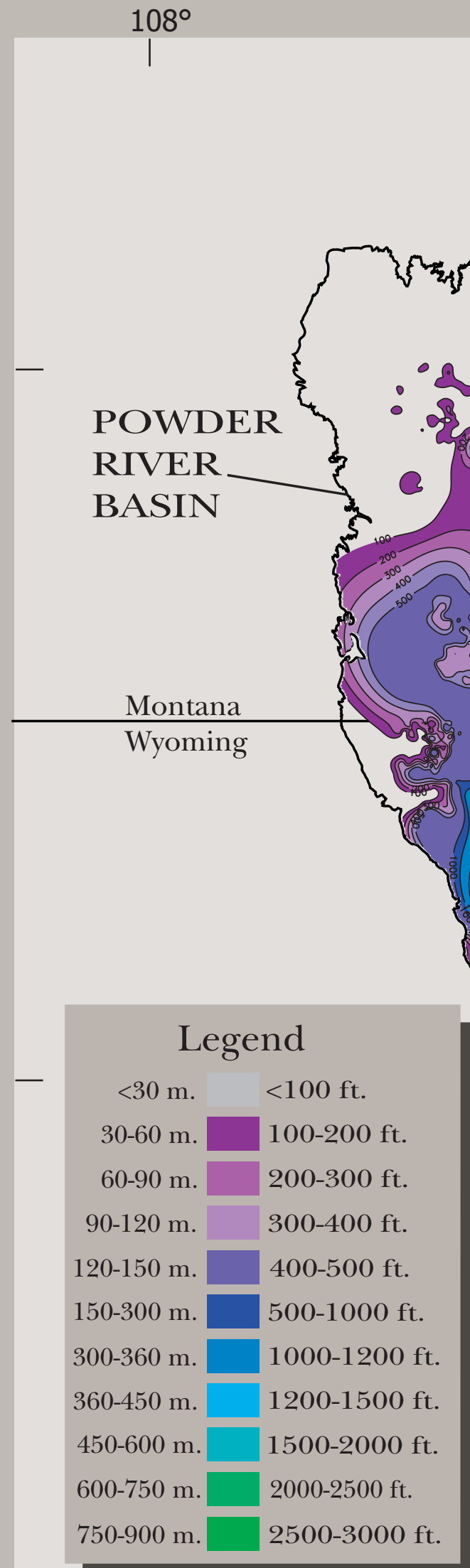

$106^{\circ}$ 


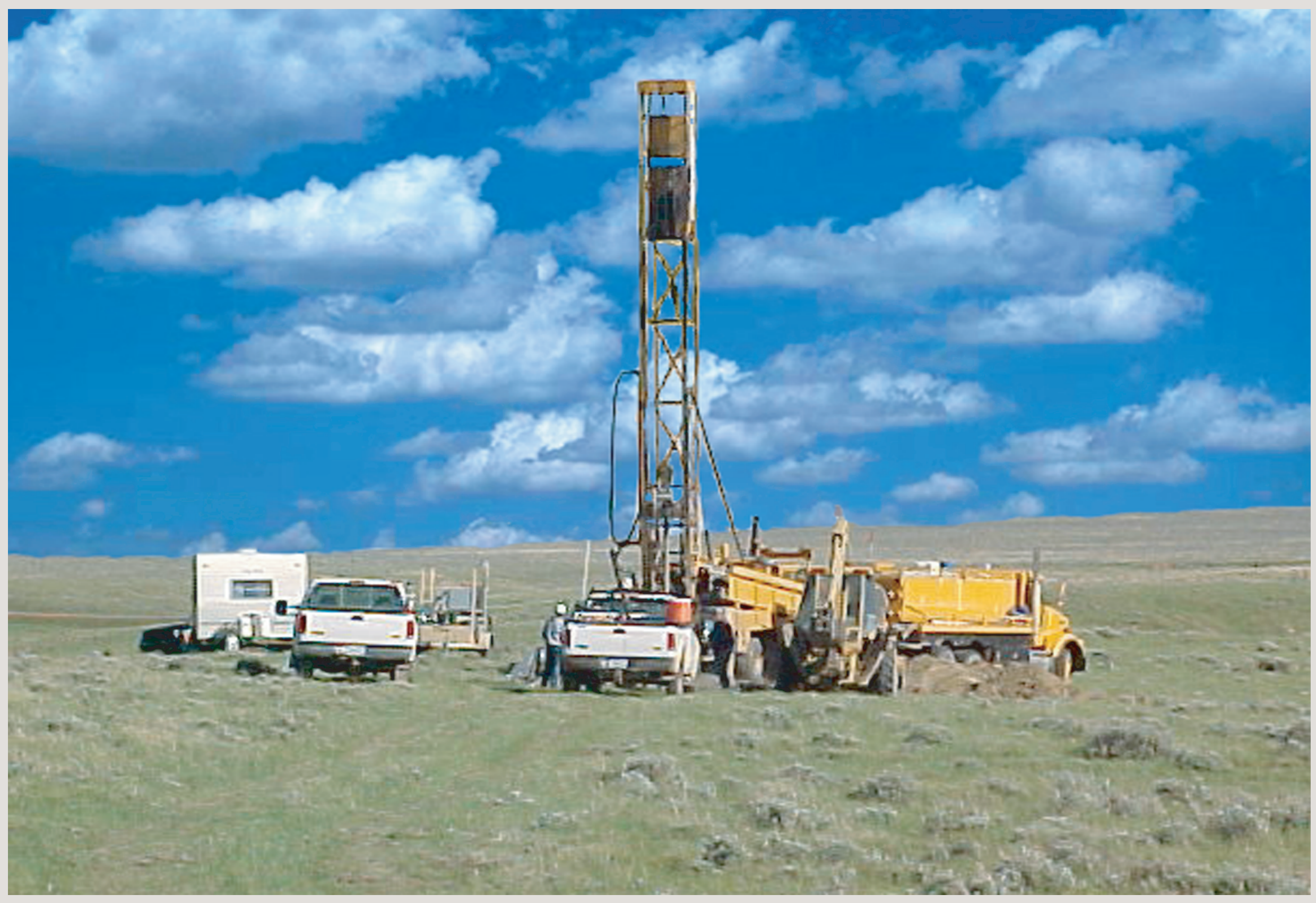

Figure 30 


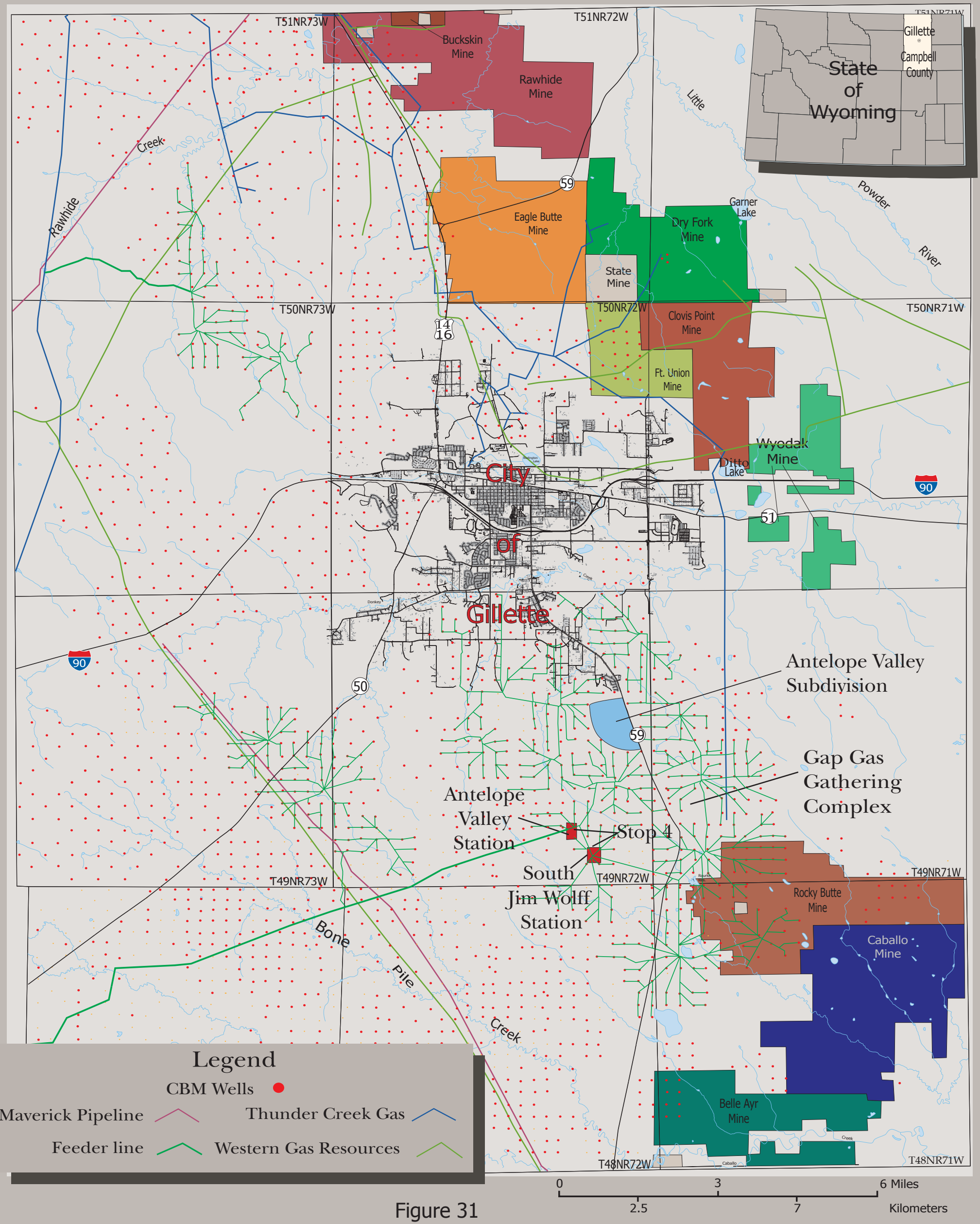




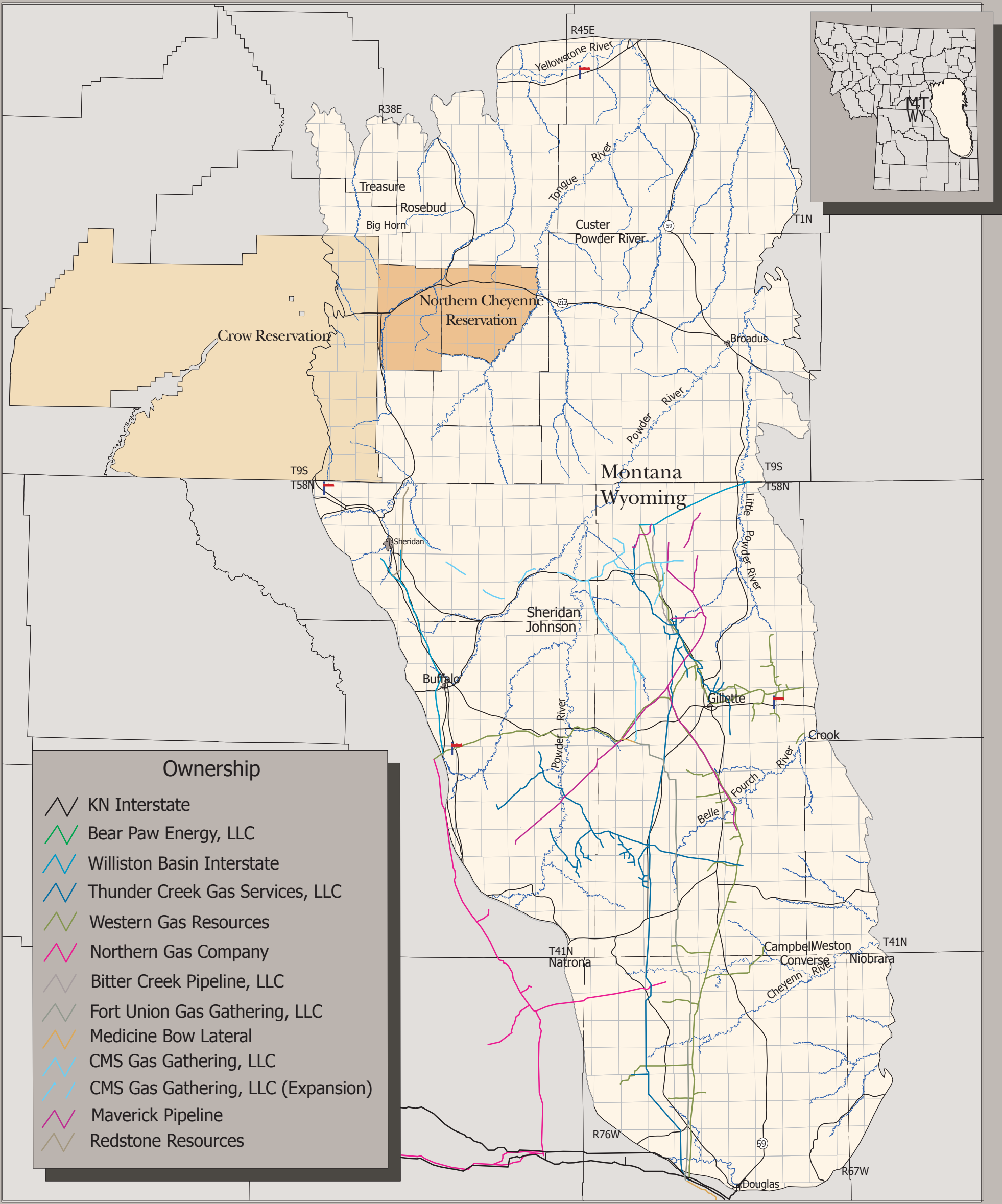


Powder River Basin Produced Water Composition

$$
\mathrm{mg} / \mathrm{L} \text { (except } \mathrm{pH} \text { ) }
$$

$h=48$

\section{Range Average DWS}

$\mathrm{pH}$
6.8-7.6
7.2
$6.5-8.5$

TDS

$300-1900$

740

500

Chloride

$5.3-64$

16

250

Sulfate

0-17

3.3

250

Bicarbonate

$330-2300$

850

Calcium

$9.1-69$

35

Potassium

4.1-19

9.3

Magnesium 3.4-46

17

Sodium

$110-710$

240

DWS = Drinking Water Standard

--- $=$ No recommended values 